\title{
Sensitive fluorescent sensing for DNA assay
}

Yu Yang, Lixia Zhao

This review focuses on novel fluorescent sensing systems for rapid, sensitive, reliable and cost-effective DNA detection in clinical diagnostics. Several materials, including conjugated polyelectrolytes, nanomaterials and molecular beacons, which exhibit attractive properties, are involved to stabilize and to amplify the signal. We describe and evaluate these different DNA analytical methods and give some pointers as to the likely directions of future developments.

(c) 2010 Elsevier Ltd. All rights reserved.

Keywords: Fluorescent; DNA; Conjugated polyelectrolyte; Nanomaterial; Molecular beacon; Review

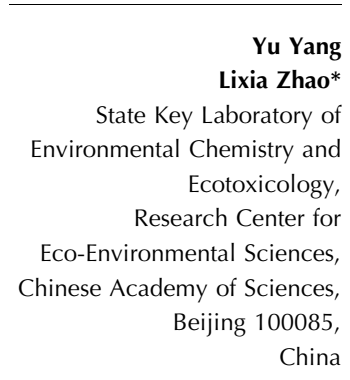

${ }^{*}$ Corresponding author. Tel./Fax: +86 1062849338 ; E-mail: zlx@rcees.ac.cn

\section{Introduction}

The enormous amount of information generated in the Human Genome Project prompted the development of DNA sensors and high-density DNA arrays [1-4]. The ability to sense and to detect ultralow concentrations of specific DNA sequences is important in clinical diagnostics, gene therapy, food safety, environment, and biodefense applications [5-11], so many researchers have turned their attention to the investigation of DNA analysis and monitoring.

Methods of detection are normally based on identifying a specific sequence by hybridizing a sequence probe to the target analyte. With or without labeling, the measurement signals can be acquired \{by, e.g., optical, surface-plasmon resonance (SPR), piezoelectric or electronic-transduction techniques\} [12-18]. Not only are fast, precise and cost-effective methodologies required, but highly selective, sensitive techniques are also needed for detection assays.

Conventional methods that use radioactive $\left[{ }^{32} \mathrm{P}\right]$-labeled nucleic-acid (NA) probes or the polymerase-chain reaction (PCR) coupled with molecular fluorophore assays offer high sensitivity of detection, but they suffer from several drawbacks (e.g., complex handling procedures, easy contamination, high cost and lack of portability) [19-22]. Recently, great efforts have been made to develop biotechnolo- gies to improve the sensitivity, the selectivity and the ease of operation for NA analysis [23-33]. Among them, DNA hybridization, offering excellent selectivity using the DNA base pair coupled with optical detection, is one of the most widely-used methods [34-36]. Usually, a fluorescent dye molecule is utilized to signal the hybridization.

In ultratrace gene analysis, signal amplification is the most critical issue and is typically achieved by coupling fluorophores (e.g., organic dyes) to the DNA probes. However, two major difficulties limit the sensitivity when these fluorophores are used. The first is the relatively low signal amplification. Because a DNA probe can be labeled with only one fluorophore or a few fluorophores, the fluorescence signal is too weak to be detected when the target concentration is low. The second challenge is the poor photostability of many fluorophores. Most organic dyes suffer serious photobleaching, resulting in irreproducible signals for ultratrace bioanalysis.

To achieve strong, photostable fluorescence signals, several novel materials \{e.g., conjugated polyelectrolytes (CPs), nanomaterials [e.g., silica, gold nanoparticles (GNPs), quantum dots (QDs) and carbon nanotubes (CNTs)], and molecular beacons (MBs) \} have been introduced for bioanalysis because of their many attractive properties, including superior optical properties, substantially greater chemical 
stability, and stability against photobleaching [37-41].

In this article, we summarize analytical applications using these novel materials in DNA detection. They cover several areas in dire need of intense investigation [e.g., classical DNA analysis, detection of single-nucleotide polymorphisms (SNPs), DNA-ligation or cleavage monitoring, and DNA delivery].

\section{Conjugated polyelectrolytes}

CPs are versatile new materials that combine features of conventional conjugated polymers and polyelectrolytes, resulting in unique electrical and optical properties that have made them ideally suited for applications in electrooptic devices, biosensors and drug delivery [42-45]. Modification of CPs with anionic or cationic functional groups yields materials that possess the properties of conjugated polymers but are also water soluble, which is essential for interfacing with biological substrates (e.g., proteins and DNA). These water-soluble conjugated polymers are attractive sensor materials because their electrical, optical and optoelectric properties can be greatly modified by small perturbations of the local environment [46].

CPs are water-soluble polymers that contain a $\pi$ delocalized backbone bearing pendant ionic functionalities [47-50]. Some CPs, including polythiophene [51], poly-fluorene [52], poly (p-phenylenevinylene) [53], poly (p-phenylene ethynylene) [54], and oligonucleotidefunctionalized polymer, were synthesized and their sensing properties were investigated. Compared with small-molecule dyes, their advantages stem from the light-harvesting and optical-signal-amplification properties of conjugated backbones with efficient intrachain and interchain energy-transfer mechanisms. CPs became of particular interest in recent years for reporting sequence-specific DNA or RNA recognition events via homogeneous assays based on fluorescence resonance energy transfer (FRET) [55-57]. Table 1 summarizes some FRET DNA detections using CPs.

Fig. 1 shows the principle of cationic $\mathrm{CP}(\mathrm{CCP})$ assays [58]. They usually employ a CCP and a fluorophore $\left(\mathrm{C}^{*}\right)$ labeled probe (e.g., PNA-C*, DNA-C ${ }^{*}$ or RNA-C ${ }^{*}$ ), which are chosen to favor FRET from the CCP (donor) to $\mathrm{C}^{*}$ (acceptor). FRET efficiency is proportional to $1 / r^{6}$, where $r$ is the donor-acceptor distance, and the integral of spectral overlap between donor and acceptor. Thus, as shown in situation A of Fig. 1, stronger electrostatic attractions between the CCP and dsDNA-C* (dsDNA: double-stranded DNA) usually induce closer donoracceptor distance and preferential FRET to dsDNA-C* ${ }^{*}$, as compared with ssDNA-C ${ }^{*}$ (ssDNA: single-stranded DNA) or $\left(\mathrm{ssDNA} \mathrm{C}^{*}+\mathrm{ssDNA}_{\mathrm{NC}}\right)$ (ssDNA $\mathrm{sC}_{\mathrm{NC}}$ : non-complementary ssDNA) in situation B. Moreover, that the emission of $\mathrm{C}^{*}$ by efficient FRET from the CCP was considerably more intense than that obtained by direct excitation at the absorption maximum of $\mathrm{C}^{*}$ demonstrated the opticalsignal-amplification properties of the CCP. We can thus monitor the presence of specific complementary DNA sequences by monitoring the CCP-to- $\mathrm{C}^{*}$ emission ratio in real time. Peng et al. synthesized a novel cationic, watersoluble, conjugated polymer, poly $(\{2,5-b i s[3-(\mathrm{N}, \mathrm{N}-$ diethylamino)-1-oxapropyl]-para-phenylenevinylene $\}$-altpara-phenylenevinylene) dibromide $\left(\mathrm{PPVNEt}_{2} \mathrm{Br}_{2}\right)$, and used it to develop a simple label-free DNA-detection assay [59]. The results illustrated that it was possible to detect specific DNA fragments in solution by using a single Cy3-labelled oligonucleotide-probe strand. The limit of detection (LOD) for complementary target DNA was $7 \mathrm{nM}$. Further optimization of the structure and the properties of CCPs may lead to simple, practical analysis platforms for DNA hybridization.

Anionic CPs (ACPs) can also provide an important optical platform for DNA analysis. Lee et al. developed a biosynthetic anionic poly(phenyleneethynylene) (PPE)DNA sensor for efficient self-signal-amplifying DNA detection in aqueous solution (Fig. 2) [60]. By using a simple carboiimide chemistry, PPE was successfully conjugated to DNA molecules by amide-bond formation. The resulting single-stranded DNA (ssDNA) coupled at the end of the polymer chains selectively hybridized with HEX (hexachlorofluorescein, a fluorescent dye)-labeled target complementary DNA. A large amount of fluorescence energy from the PPE was efficiently transferred to the target HEX-DNA upon DNA/DNA hybridization,

Table 1. One-step or two-step fluorescent resonance-energy transfer (FRET) process to detect DNA using conjugated polyelectrolytes (CPs)

\begin{tabular}{|c|c|c|c|c|}
\hline & Donor 1 & Acceptor 1 (or as Donor 2) & Acceptor 2 & Ref. \\
\hline \multirow[t]{7}{*}{ CCPs } & Poly(p-phenylenevinylene) & Cy3 & - & [59] \\
\hline & Poly(fluorene-co-phenylene) & Fluorescein & Ethidium bromide & {$[55]$} \\
\hline & & Fluorescein & - & {$[48,66]$} \\
\hline & & Thiazole orange & - & [64] \\
\hline & & Texas Red & - & [65] \\
\hline & & Cy5 & - & [67] \\
\hline & Polythiophene & Alexa Fluor 546 & - & {$[45]$} \\
\hline ACPs & Poly ( $p$-phenylene ethynylene) & Hexachloro-fluorescein & - & {$[60]$} \\
\hline Complex of CCPs and ACPs & Poly(fluorene-co-phenylene) ACP:CCP = 85:15 & Benzothiadiazole & Texas Red & {$[56]$} \\
\hline
\end{tabular}




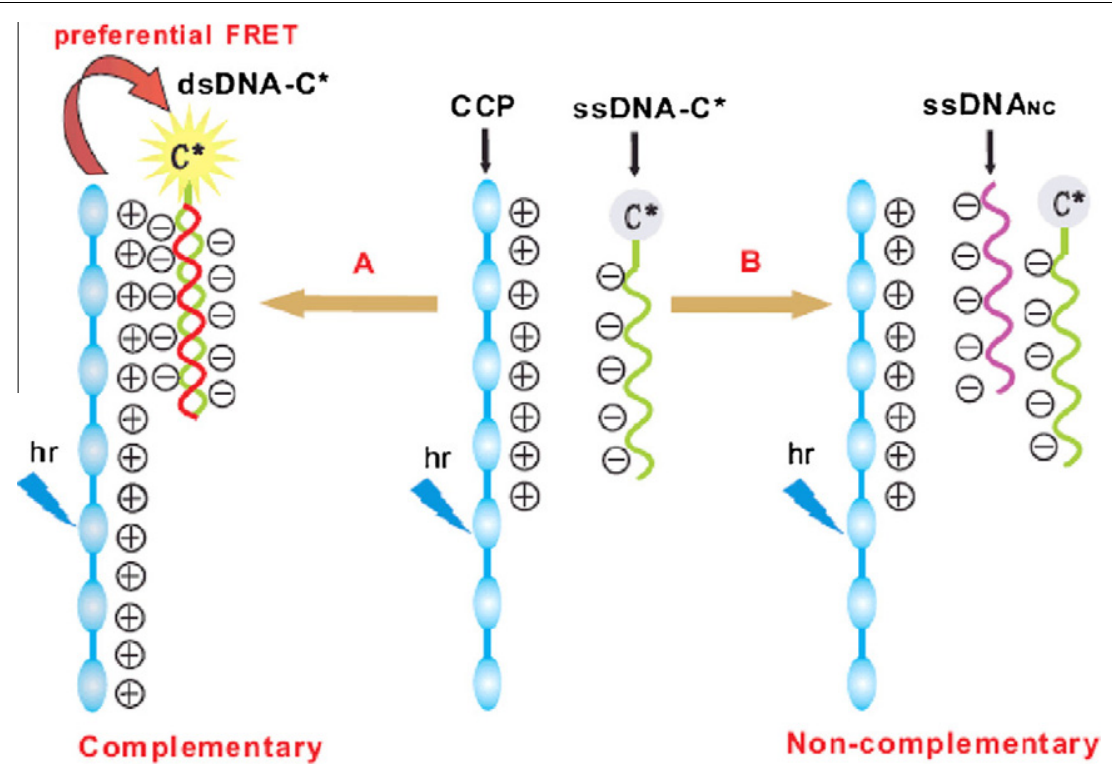

Figure 1. Use of a cationic conjugated polyelectrolyte (CCP) with a single-stranded DNA fluorophore $\left(\mathrm{C}^{*}\right)$ (ssDNA-C*) probe to detect a complementary ssDNA [58].

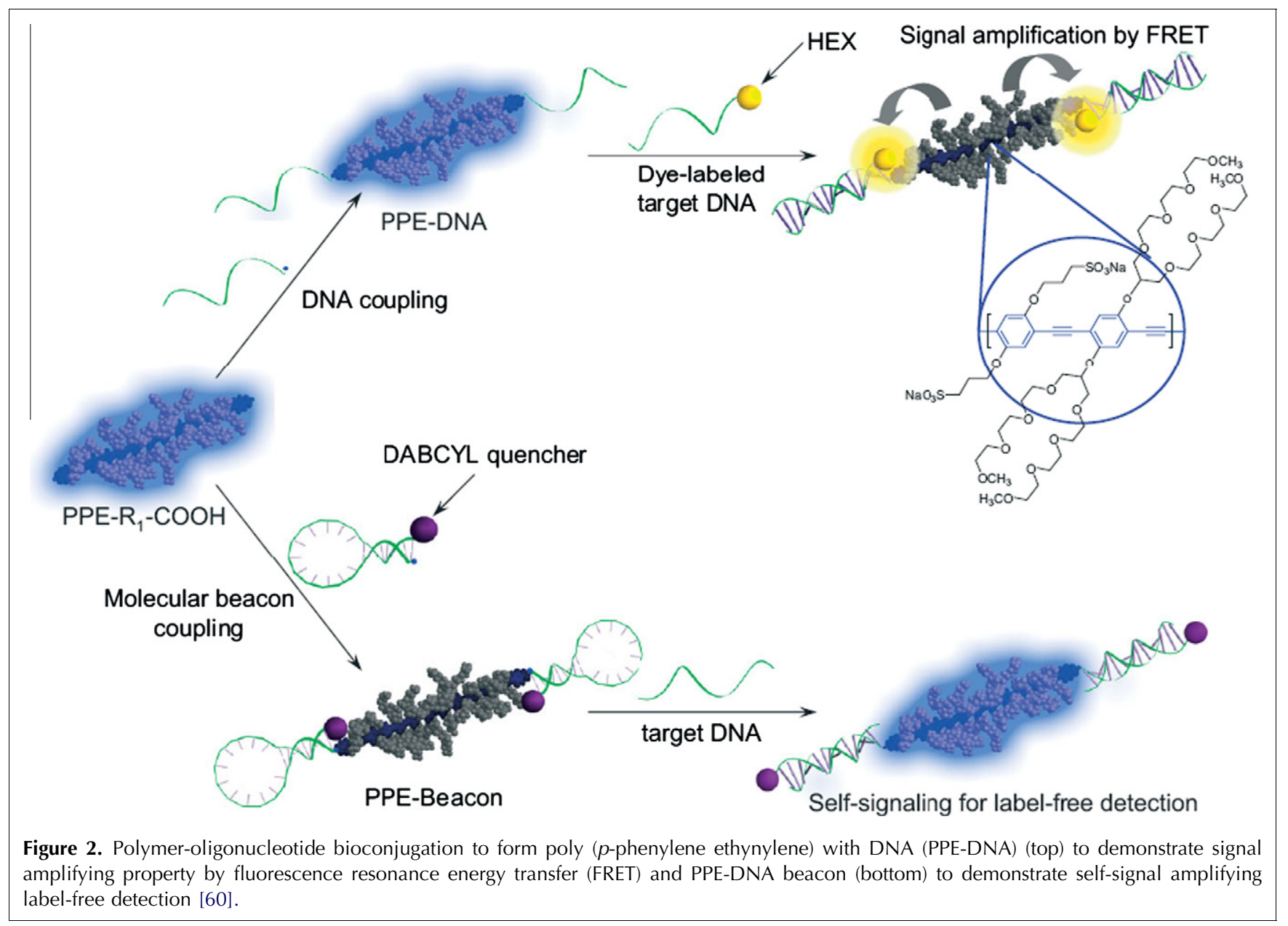




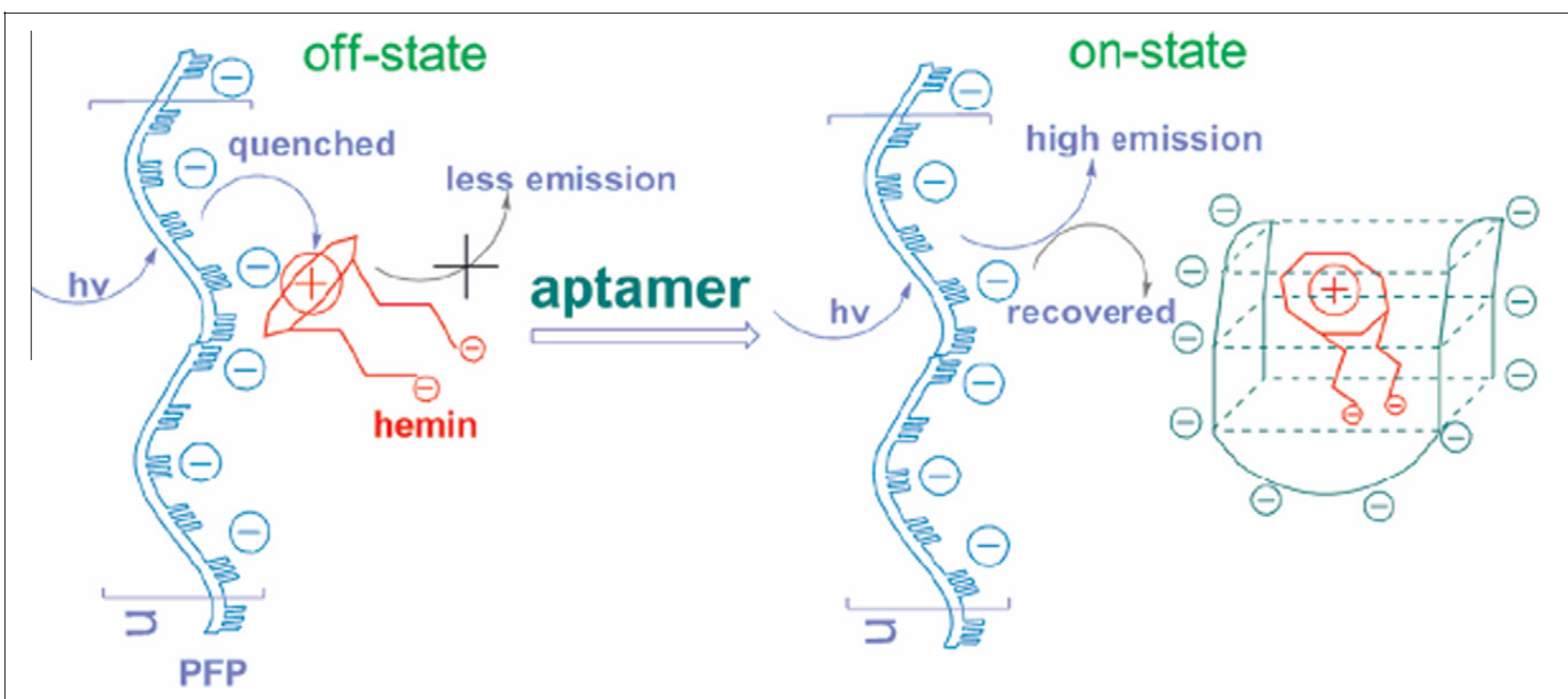

Figure 3. Principle of the fluorescent switch combining (9,9-bis(6'-phosphate-hexyl)fluorenealt-1,4-phenylene) sodium salt (PFP), hemin and hemin aptamer [61].

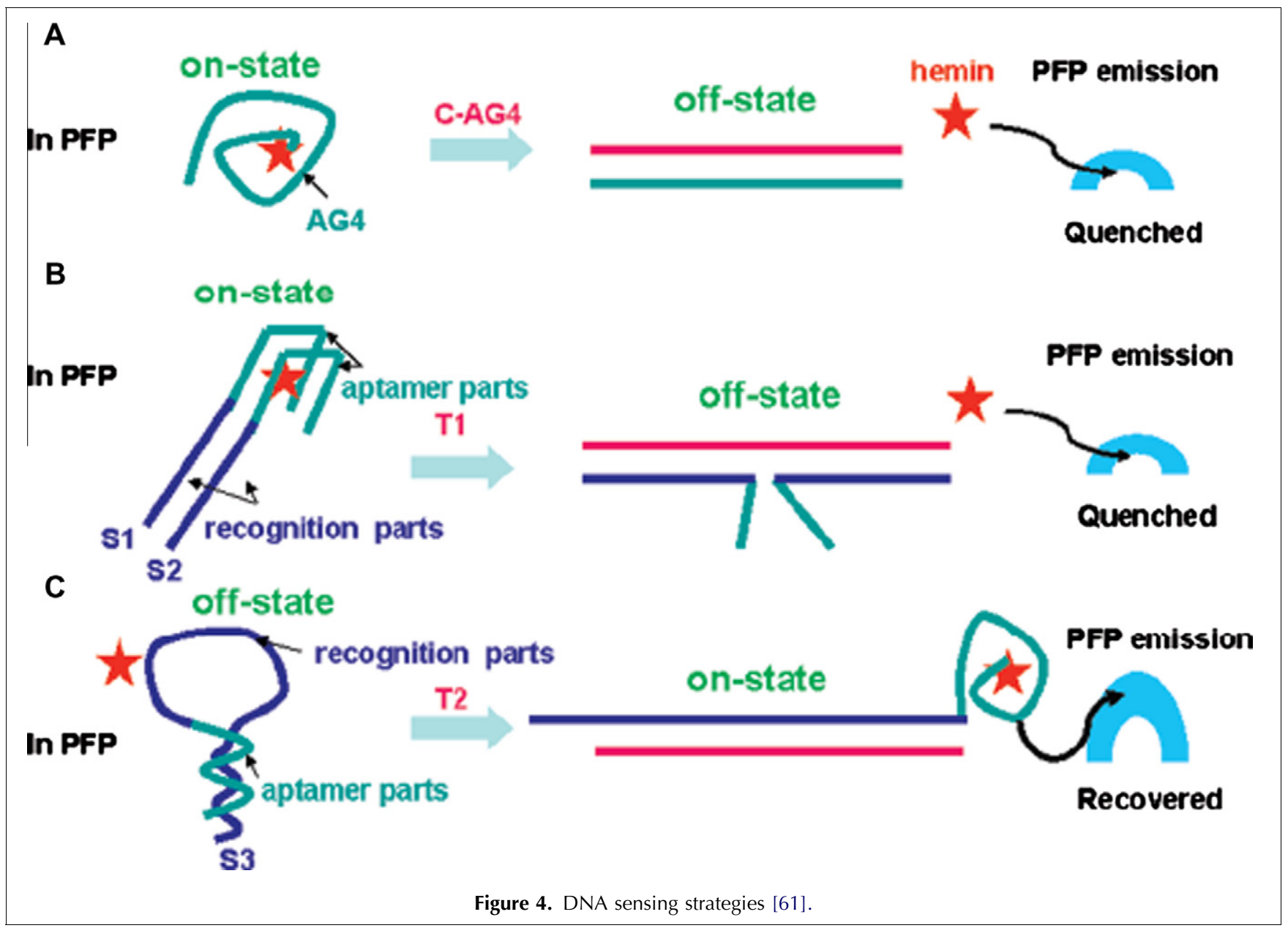


resulting in large signal amplification, so the PPE-DNAhybrid-based DNA detection system successfully showed large signal amplification through FRET. In addition, they also covalently connected the PPE with an oligonucleotide probe that had a quencher at the end. This oligonucleotide MB could form a hairpin-shape in buffer solutions resulting in the fluorescence quenching of the PPE but unfolded to form a DNA double helix upon addition of complementary DNA, turning on the fluorescence emission of the PPE. Hence, in this molecular design, the completely water-soluble and highly-fluorescent conjugated polymer replaced a fluorescent dye of the conventional MB to allow label-free, self-signalamplifying detection of target DNA upon hybridization.

$\mathrm{Li}$ et al. constructed a fluorescent switch combining hemin, hemin aptamer, and a newly synthesized ACP \{i.e. poly $\left(9,9\right.$-bis $\left(6^{\prime}\right.$-phosphate-hexyl)fluorenealt-1,4phenylene) sodium salt (PFP)\} [61]. PFP acted as the fluorescent producer to realize a label-free DNA-related detection (Fig. 3). In the "off" state, the fluorescence of PFP could be sensitively quenched by hemin, while in the "on" state, hemin aptamer reacted with hemin and formation of the aptamer/hemin complex would recover the fluorescence intensity.

To testify to the universality and the practicality of the fluorescent switch, a series of DNA-related sensing processes were developed, including three DNA-sensing strategies (Fig. 4). In these three cases, the LODs for DNA assay were $1.4 \mathrm{nM}, 9 \mathrm{nM}$ and $0.6 \mathrm{nM}$, respectively. Through this sensing system, derived from the fluorescent switch, a simple, universal sensing platform was presented, so that all different DNA sequences could be detected, and the commonly used labeling, modification, and separation steps were avoided. In addition, ACPs were successfully applied to label-free aptamer-based recognition and DNA sensing. It helped to prove that, besides CCPs, ACPs also possessed promising potential in these fields.

CPs that provide amplified signals of hybridization events have been widely employed to detect DNA. Compared to small-molecule-based assays, CPs collect the action of a large number of absorbing units, and the transfer of excitation energy along the whole backbone to the chromophore reporter results in amplification of fluorescence signals, which significantly improves detection sensitivity. CP FRET-induced signal amplifications are affected by several factors \{e.g., charge ratio, distance, spectral overlap and dipole orientation between donor (CP) and acceptor (fluorophore) [62-66]\}. Because the detection signals generated by these assays are magnified, there is no need to spend time on complex PCR protocols to increase the concentration of specific NA sequences to detectable levels. Use of standard optical equipment and minimal DNA modification make their practical implementation very convenient. These DNAhybridization assays based on FRET are therefore

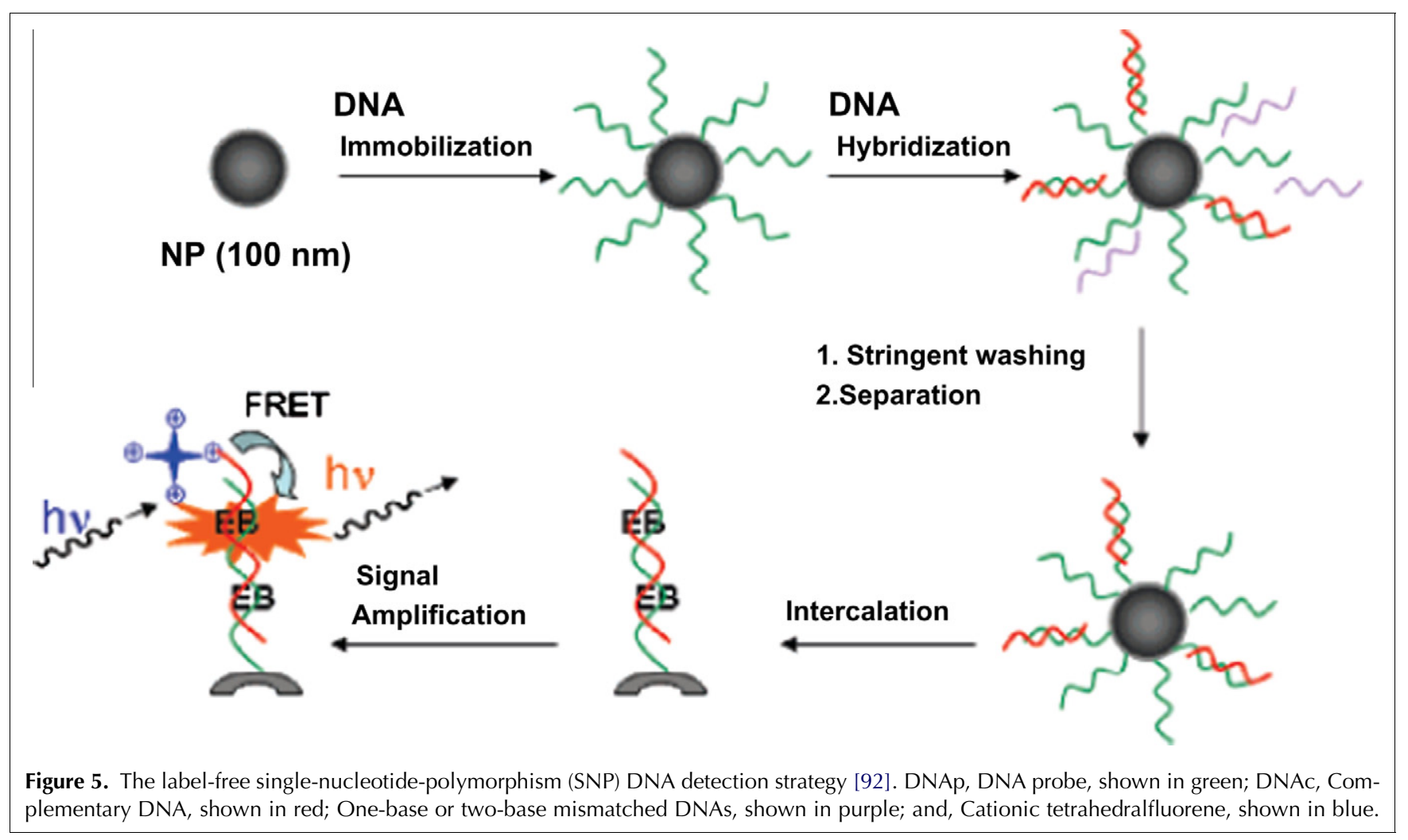


attractive due to their real-time testing, high sensitivity, and simplicity of operation. Furthermore, recent studies demonstrated that this FRET technique using CCPs can be successfully extended to microarray assays [67-69], thus suggesting it has potential in high-throughput screening.

\section{Nanomaterials}

The rapid development of nanoscale science and technology has resulted in the successful synthesis and characterization of a variety of nanomaterials \{e.g., nonmetallic NPs [70], metallic NPs [71], semiconductor
1.

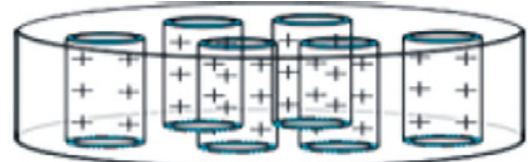

2.

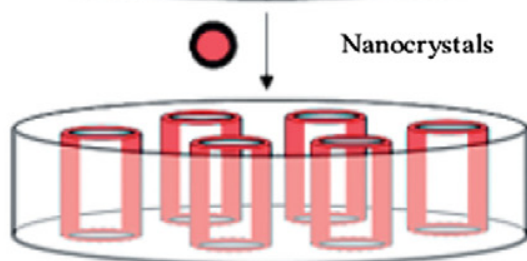

3.

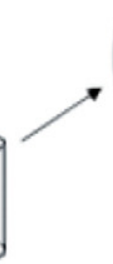

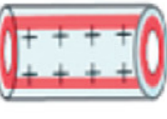

4.

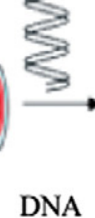

5.
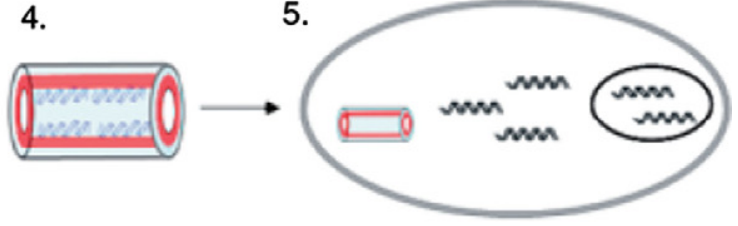

Figure 6. Preparation of fluorescent nanotubes (fNTs) and its application in gene delivery [94]. 1) The AAO membrane coated with a silica layer was modified with APTMS to form a polycationic surface. 2) Core-shell nanocrystals were incorporated onto the polycationic surface. An additional silica layer and a subsequent APTM coating were layered over the nanocrystals. 3) The fNTs with polycationic inner surfaces were generated by removing the AAO membrane. 4) The plasmid DNA was inserted into the nanotubes to form a DNA/fNT complex. 5) The DNA/fNT complex entered the cell. The DNA may be released from the complex and subsequently transcribed in the nucleus.

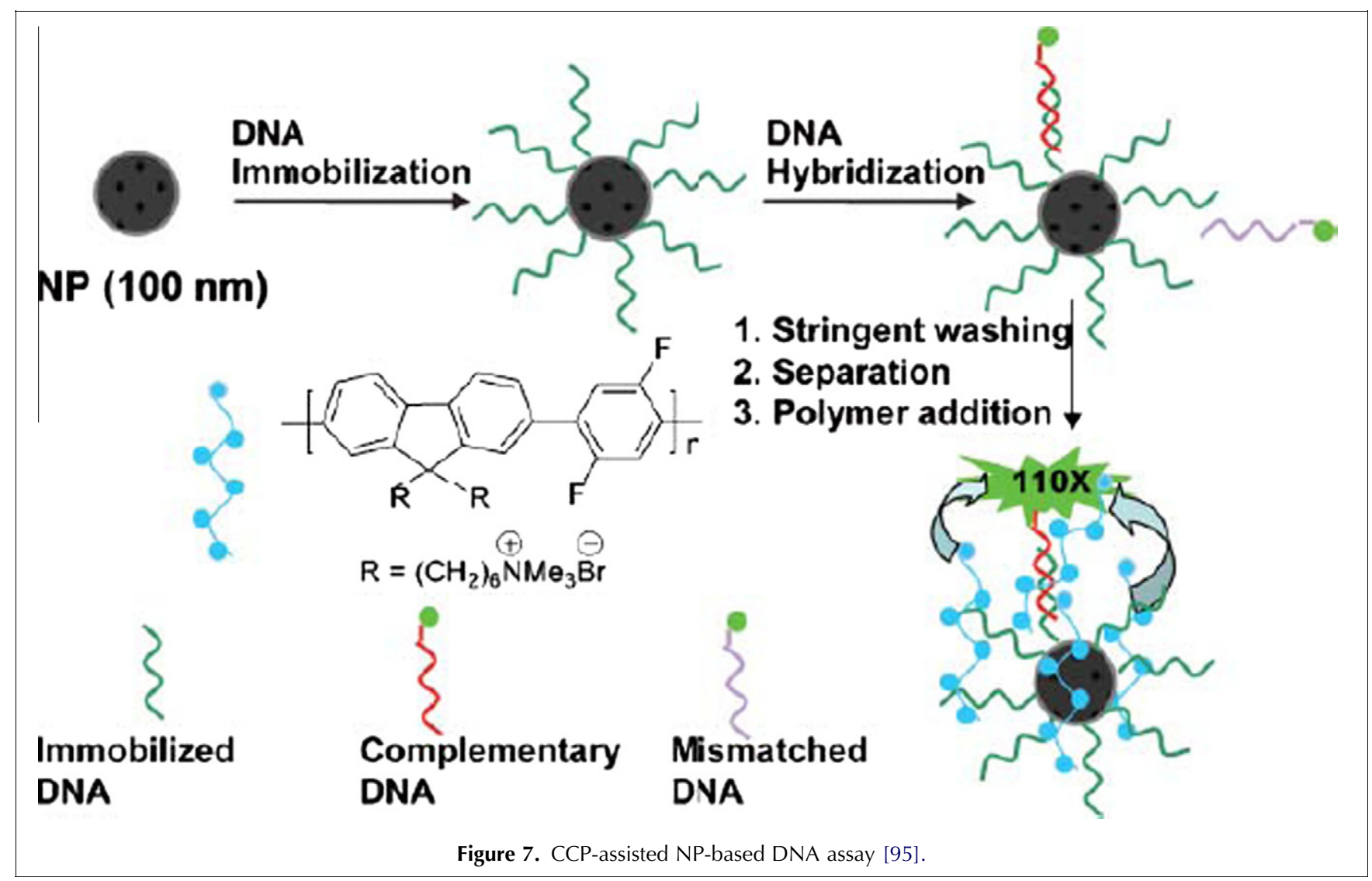


nanocrystals (QDs) [72,73] and CNTs [74,75]\}. These nanomaterials have been shown to possess unique optical [76,77], electronic [78], magnetic [79,80] and catalytic properties [81], making them ideal candidates for signal generation and transduction in sensing. However, a sensing system requires at least two components:

- a target-recognition element; and,

- a signal-transduction element.

Nanomaterials do not intrinsically possess the targetrecognition abilities necessary for selective binding and sensing, so integration of functional DNA with nanomaterials provides new hybrid systems that combine the specific molecular recognition of functional DNA with the diverse, strong signal transduction of nanomaterials. This novel combination has yielded stimuli-responsive nanomaterial assemblies, and various types of sensors for selective and sensitive detection of a wide range of analytes [82,28,83-85].

In the following, we discuss recent advances in fluorescent sensing for DNA assay through integration of functional DNA with different nanomaterials (e.g., silica NPs, GNPs, QDs and CNTs).

\subsection{Silica-based nanoparticles}

Silica NPs have been investigated intensively and have proved to be an ideal substrate, since they are very stable, chemically and thermally [86-88], and possess several advantages. Silica NPs are easy to separate via centrifugation during particle preparation, surface modification, and other solution-treatment processes. Furthermore, silica NPs are more hydrophilic and more biocompatible, and are not subject to microbial attack, and no swelling or change in porosity occurs with changes in $\mathrm{pH}$. Silica has well-established chemistries that allow surface modification with various functional groups (e.g., amine, thiol, carboxyl and methacrylate). Silica NPs can be further modified with biomolecules for biological applications [89-91].

Wang et al. presented a simple, efficient silica-NPbased platform with optically-enhanced signals that allowed label-free sequence-specific DNA detection with SNP selectivity (Fig. 5) [92]. The overall detection could be separated into two consecutive stages (i.e. specific DNA recognition and signal amplification). The signal transduction was achieved by combining two recognition events (i.e., the specific base-pair recognition between the probes immobilized on the NP surface and the targets and the electrostatic interaction between the tetrahedralfluorene and the DNA duplex that allowed ethidium-bromide (EB) intercalation). In the case of a complementary DNA sequence, addition of DNAc resulted in the formation of a double helix (NP-DNAp/ DNAc) and the intercalation of $\mathrm{EB}$ within the duplex structure. Excitation of the tetrahedralfluorene led to energy transfer from tetrahedralfluorene to EB, resulting in sensitized EB emission. In the case of non-complementary sequences, the hybridization products could not sustain stringent washing. Little or no EB intercalation was possible. The distance between the tetrahedralfluorene and EB remained too large for efficient energy transfer. Compared with the solution-based homogeneous assay, which could not offer sequence-specific detection, this method provided fast detection of oligonucleotides with high sensitivity and SNP selectivity and opened up possibilities for future development of integrated and portable devices for diagnostics or forensic investigations.
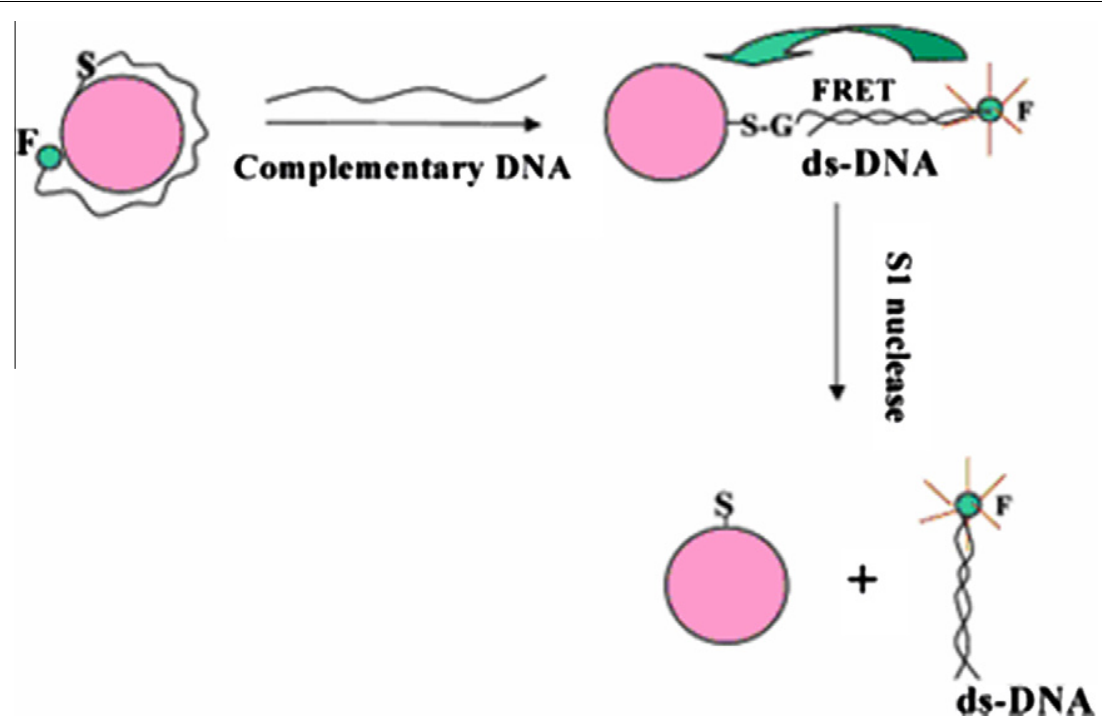

Figure 8. DNA cleavage process when DNA was attached to gold nanoparticle through the $-\mathrm{SH}$ group, in which the circles represent the gold nanoparticle and $\mathrm{F}$ represents the fluorophore [111]. 

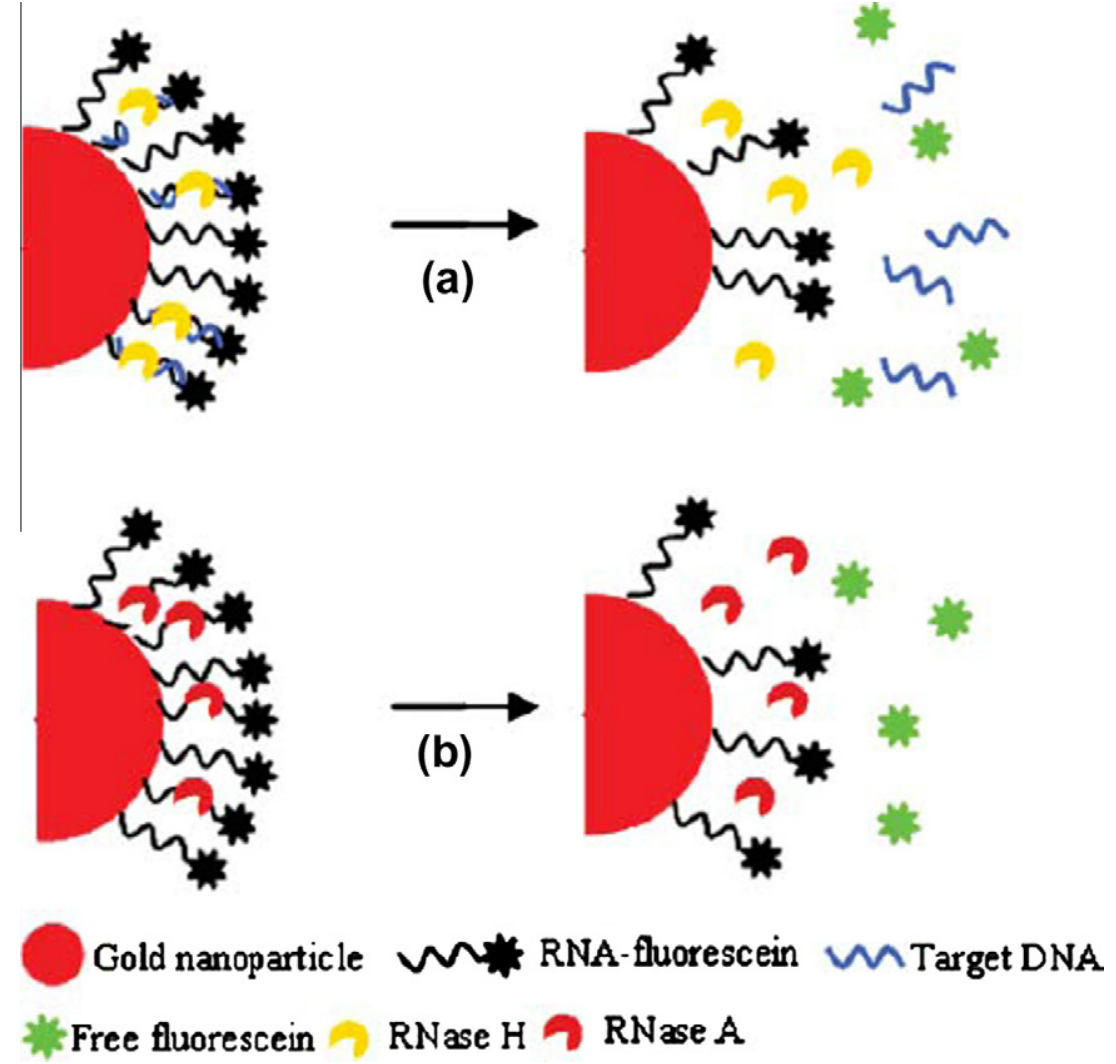

Figure 9. RNA-dye-modified GNPs for detecting DNA, RNase H, and RNase A [112].

Unlike NPs or nanorods, NTs have a unique, hollow structure, which allows the modification of their inner surface and filling with specific biomolecules [93]. In addition, the tube structure may act as a physical shield for the inserted biomolecules and provide advantages for biomolecule delivery. At present, the applications of NTs as biomolecule carriers are still very rare. Chen et al. developed a simple method for the preparation of fluorescent nanotubes (fNTs) and their use for gene delivery (Fig. 6) [94]. In this work, fNTs with an inner diameter of hundreds of nanometers were synthesized by sol-gel reaction using an anodic aluminum oxide (AAO) membrane as a template. Green fNTs and red fNTs were obtained by incorporating $\mathrm{CdSe}$ and $\mathrm{ZnS}$ core-shell semiconductor nanocrystals with diameters of about 4 $\mathrm{nm}$ and $8 \mathrm{~nm}$, respectively.

The fluorescent nature of the NTs allowed us to visualize their localization in living cells. The inner surfaces of the NTs were coated with positive charges to provide efficient DNA loading. We found that NTs filled with the gene-encoding green fluorescent protein (GFP) entered monkey kidney COS-7 cells and that these cells exhibited GFP expression. These results demonstrated a novel application of NTs in biomolecule delivery.

Wang et al. described silica-NP-assisted DNA assay for optical signal amplification of a CCP-based fluorescent sensor, which allowed detection of target DNAs at a concentration of $10 \mathrm{pM}$ [95]. Fig. 7 shows how to take advantage of the optical amplification of CCPs and easy separation of NPs. The approach begins with probe immobilized NPs in solution. If the added DNA is complementary to the probe, the NPs can capture the target and bring fluorescein chromophore $\left(\mathrm{C}^{*}\right)$ close to the surface. In the absence of the complementary sequence, no $\mathrm{C}^{*}$ is attracted to the NPs after stringent washing and separation steps. Only when the complementary sequence is present in the initial solution are CCP (donor) and $\mathrm{C}^{*}$ (acceptor) present in the final mixture, allowing intense acceptor emission upon polymer excitation.

There are some surface-modification schemes for silica NPs [96-98]. The silica-NP-surface design involves optimum balance of inert and active surface functional groups to achieve minimal NP aggregation and reduce NP non-specific binding. Using these surface-modification schemes, fluorescent dye-doped silica NPs can be readily conjugated with biomolecules and used as highly fluorescent, sensitive, and reproducible labels in DNAchip analysis and various other bioanalytical applications [99-101].

\subsection{Gold nanoparticles}

The use of GNPs as labeling tags in diagnostic development has attracted much interest in recent years. GNPs offer unique optical properties from their SPR, high 

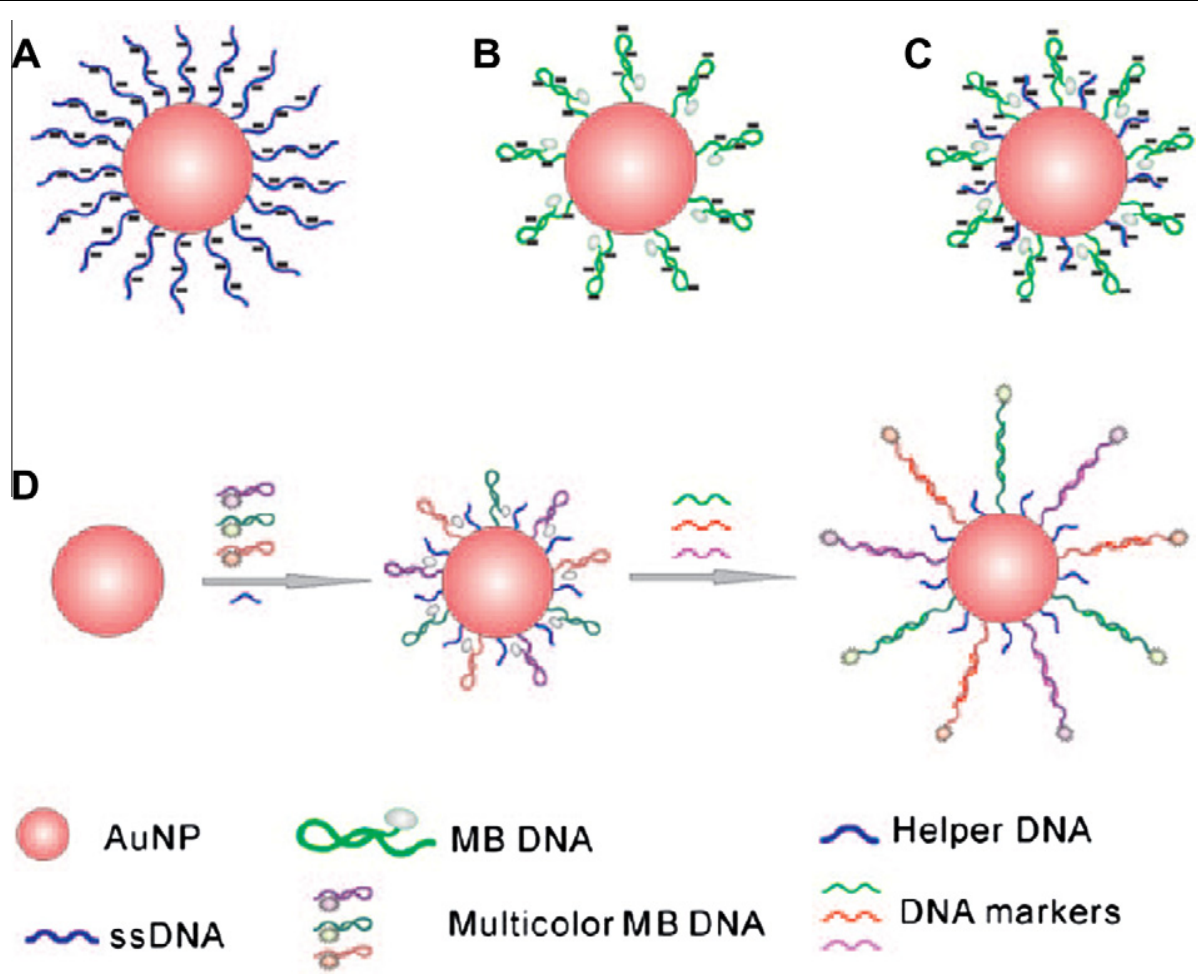

Figure 10. Assembly of nanoMBs [113]. A) AuNPs self-assembled with densely loaded linear probes (stable nanoparticles); B) AuNPs self-assembled with sparsely loaded stem-loop probes (easily aggregated); C) AuNPs self-assembled with stem-loop probes and helper oligonucleotides (stable nanoMBs); D) AuNPs self-assembled with multi-color stem-loop probes and helper oligonucleotides (stable multi-color nanoMBs), ssDNA = single-stranded DNA.

surface-area-to-volume ratio, extremely high quenching efficiency and biocompatibility to replace conventional fluorophores [102-104,11,105]. Also importantly, conjugation chemistry for protein and DNA binding at the surface of GNPs has been well established, and paves the way for using biomolecule-GNP conjugates in biosensing applications [106-110].

Ray et al. reported a GNP-based FRET assay to monitor the cleavage of DNA by single-strand-specific nucleases [111]. The assay involved two steps (Fig. 8):

(1) Cy3-labeled DNA-coated GNPs were hybridized with the complementary NA containing one nucleotide less. Hybridization was followed by fluorescence quenching of the dye by GNPs; and,

(2) a GNP/dye DNA duplex was treated with S1 nuclease to cleave the DNA, and the kinetics of the cleavage process was monitored from the recovery of the dye fluorescence. After cleavage, 250-fM concentration of fluorophore-tagged ds-DNA could be observed.

Kim et al. modified GNP with RNA-fluorescein conjugates and utilized it to detect specific DNA sequences and various RNA nucleases [112]. Two kinds of nucleases, RNase $\mathrm{H}$ and RNase A, were used. To identify a DNA strand, they utilized the unique property of RNase $\mathrm{H}$ for cleaving the RNA phosphodiester bonds only when it was contained in an RNA-DNA heteroduplex, while not digesting the DNA within the heteroduplex, singlestranded RNA, double-stranded RNA or DNA. RNase A was non-specific nuclease.

Fig. 9 shows the approach to detection using enzymatic degradation of our GNP-RNA-dye conjugates. The fluorescein-labeled RNA molecule in an intact conjugate exhibited very low fluorescence due to the proximity of the quenching moiety, the GNP. However, upon RNA degradation and diffusion of the fragments into solution, a strong increase in fluorescence intensity was seen. This method provided a basis for detecting a specific sequence of DNA (Fig. 9(a)) and RNase A (Fig. 9(b)) by monitoring RNA cleavage using a standard fluorimeter. In this case, additional signal amplification was provided by the enzymatic cycling of RNase $\mathrm{H}$ (the DNA target was not degraded by the enzyme and may form a heteroduplex with many RNA probes during the incubation time). A sensitivity limit of $10 \mathrm{pM}$ DNA was obtained. Also, the detection sensitivities for RNase $\mathrm{H}$ and RNase A were 43 $\mathrm{mu}$ and $0.73 \mathrm{fM}$, respectively.

Due to the enzymatic digestion of the RNA portion of the conjugates by either RNase $\mathrm{H}$ or RNase A, fluorescein diffused away from the GNP beyond distances of efficient energy transfer, leading to a detectable fluorescent signal. The GNPs were modified with a 26-base 


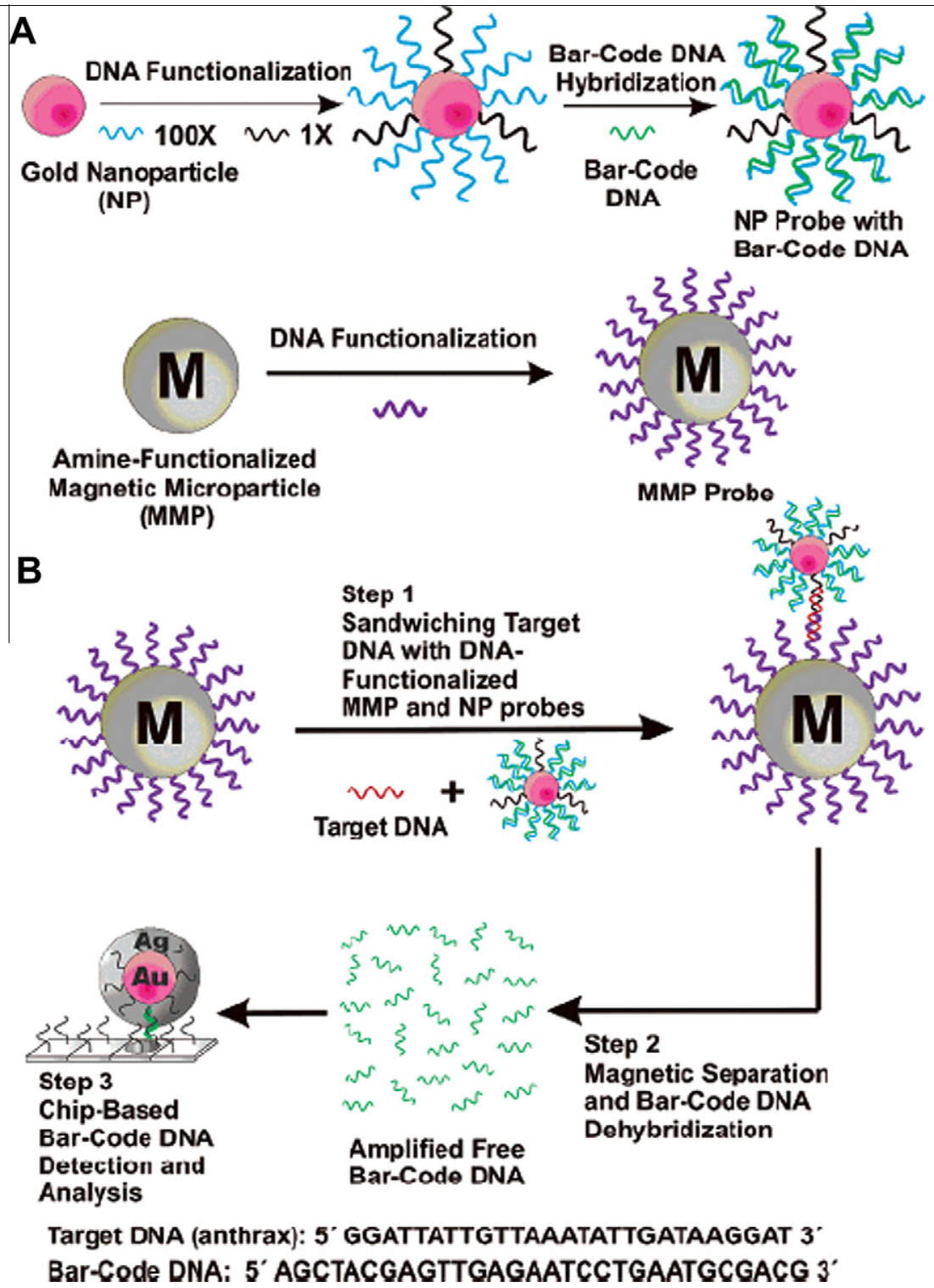

Figure 11. The DNA-BCA assay [114]. (A) Nanoparticle and magnetic microparticle probe preparation; (B) Nanoparticle-based PCR-less DNA amplification scheme.

RNA molecule containing a 59-hexylthiol and a 39fluorescein. DNA was detected through hybridization to the RNA portion of the probes followed by RNase $\mathrm{H}$ digestion. RNase $\mathrm{H}$ could be detected by pre-forming an RNA-DNA heteroduplex and monitoring probe degradation. RNase A was detected using the single-stranded conjugates.

Song et al. used relatively large GNPs $(15 \mathrm{~nm})$ to construct multi-color nanoscale MBs (nanoMBs) (Fig. 10) [113]. Such large GNPs possessed strong SPR absorption, which exceeded that of 1-nm or 2-nm GNPs by orders of magnitude. More importantly, small GNPs could accommodate only one or several oligonucleotides, whereas large GNPs allowed anchoring of many oligonucleotides at a single particle, thus providing the opportunity to construct multi-color nanoMBs. Song et al. examined the sequence-discrimination ability of nanoMBs toward single-base-mismatched DNA. Importantly, target DNA with one mismatch led to only about half the fluorescence of the complementary DNA. This difference demonstrated that nanoMBs retained the high sequence specificity offered by the conformational constraint of stem-loop structures.

Nam et al. reported a PCR-less target-DNA-amplification method that relied on novel two-component oligonucleotide-modified GNPs and single-component oligonucleotide-modified magnetic microparticles (MMPs), and subsequent detection of amplified target DNA in the form of bar-code DNA using a chip-based detection method [114]. The bio-bar-code amplification 


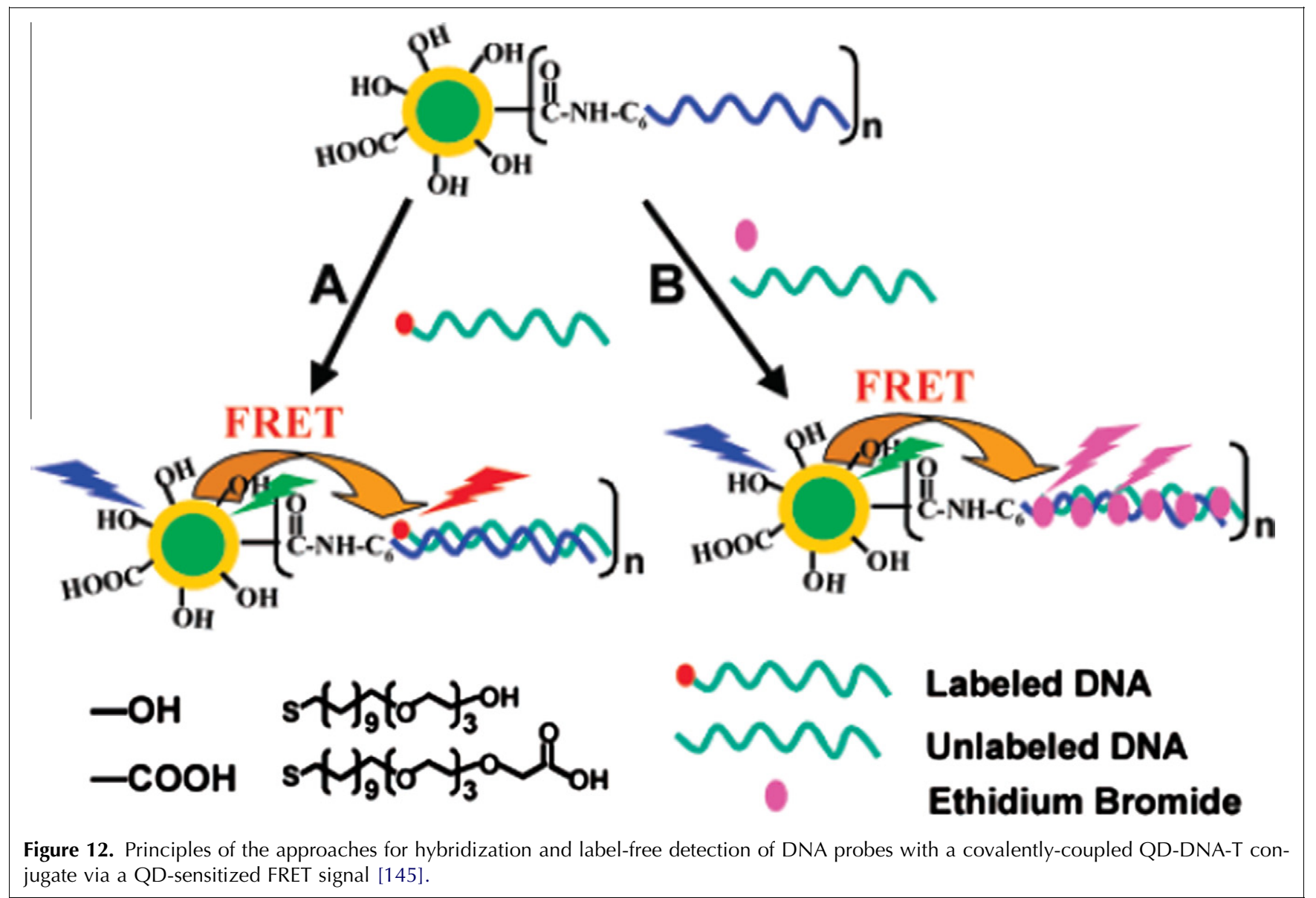

(BCA) approach utilized oligonucleotide-modified NPs for signal amplification and MMPs for easy, clean separation from unreacted elements (Fig. 11). For DNA detection via the BCA approach, two types of probes have been prepared (Fig. 11A):

(1) an iron-oxide MMP, which had a magnetic ironoxide core with an amine-modified silane coating. These particles were functionalized with alkane- thiol-capped oligonucleotides that were complementary to one 12-mer portion (5'ATTGATAAGGAT 3') of a target sequence using a sulfosuccinimidyl 4-N-maleimidomethyl cyclohexane-1-carboxylate (sulfo-SMCC) linker; and,

(2) a GNP (30 nm), modified with two types of oligonucleotides [i.e. one, which was complementary to the target sequence of interest (5' GGATTATTGTT

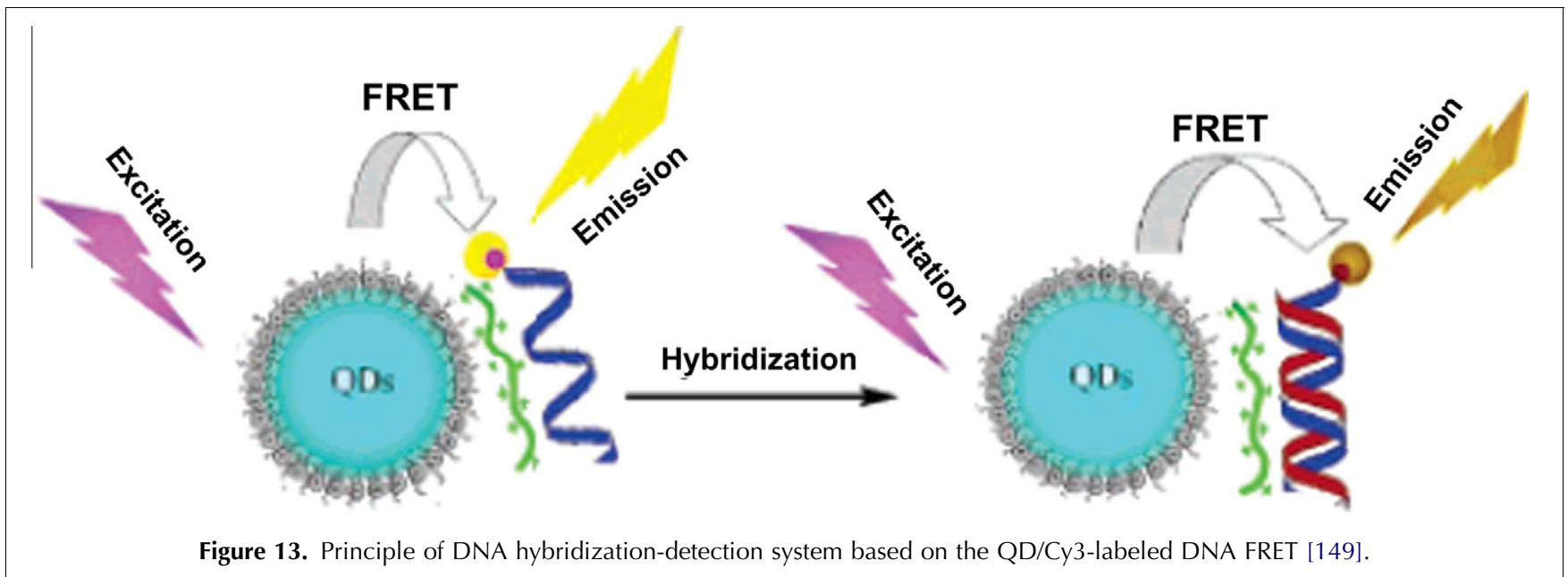



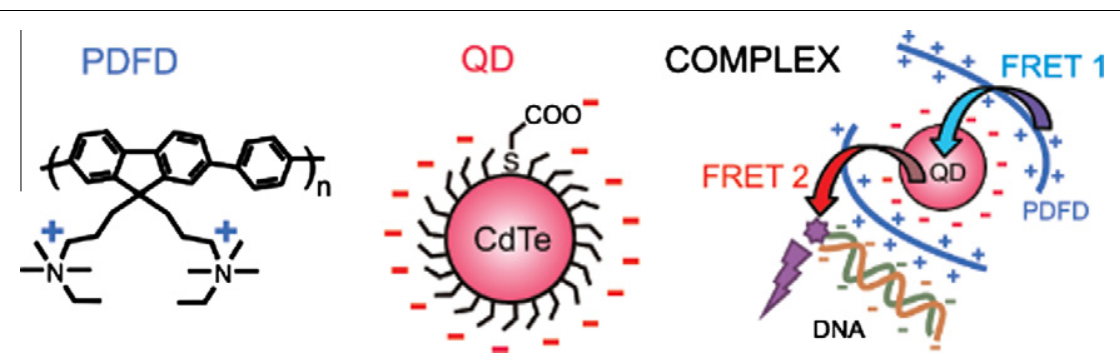

Figure 14. Chemical structure of PDFD, a TGA-capped CdTe QD and the PDFD/QD/dye-labeled DNA complex used to detect DNA hybridization through a cascaded double FRET. Upon optical excitation of PDFD and QDs, energy transfer took place from the PDFD to the QDs (FRET 1) and from the QDs to the dye-labeled DNA (FRET 2) [150].

AAAT 3') and different from the region recognized by the MMP, and the other, which was complementary to a bar-code sequence that was a unique identification tag for the target sequence].

The NPs were loaded with the target-binding and barcode-binding DNA by treating citrate-stabilized particles with a solution containing the two alkyl-thiol capped oligonucleotides at a 100:1 ratio. This ratio provided one route for target amplification because the barcode DNA rather than the target DNA was identified in the BCA approach. It would be a significant advance to be able to use the BCA to detect DNA targets at low attomolar $\left(\mathrm{zM}=10^{-21} \mathrm{M}\right)$ levels. Indeed, an advantage of the DNA-BCA approach over conventional microarray sandwich assays is that the entire assay can be carried out in 3-4 h, regardless of target concentration. The system has an excellent dynamic range and is ideally set up for multiplexing.

The optical property of GNPs is dramatically affected by their size, shape and surrounding surface environments. Combining new capabilities for controlling particle size and composition with versatile surface- modification approaches allows the design of opticallyencoded and chemically-encoded GNP probes. Furthermore, DNA microarrays based on GNP labeling have become promising tools for fast, highly-parallel DNA detection [115-118].

\subsection{Quantum dots}

The unique size-dependent, narrow, symmetric, bright, and stable fluorescence of QDs has made them powerful tools for studying a wide range of biological problems, from biological imaging and cell tracking and trafficking to novel multiplexed sensors [119-123]. Concomitant to these advances has been the development of a variety of QD surface chemistries and QD bioconjugates. QD surface chemistries have included thiol-alkyl acid ligands $[122,124,125]$, thin silica shells [126,127], amphiphilic polymers [128-131], and phospholipids [132]. QD bioconjugates have included oligonucleotides [133-136], aptamers [137,138], antibodies [139], and proteins [140,141].

Due to their tunable, narrow-band emission and broad excitation spectra, QDs are excellent donors for FRET-
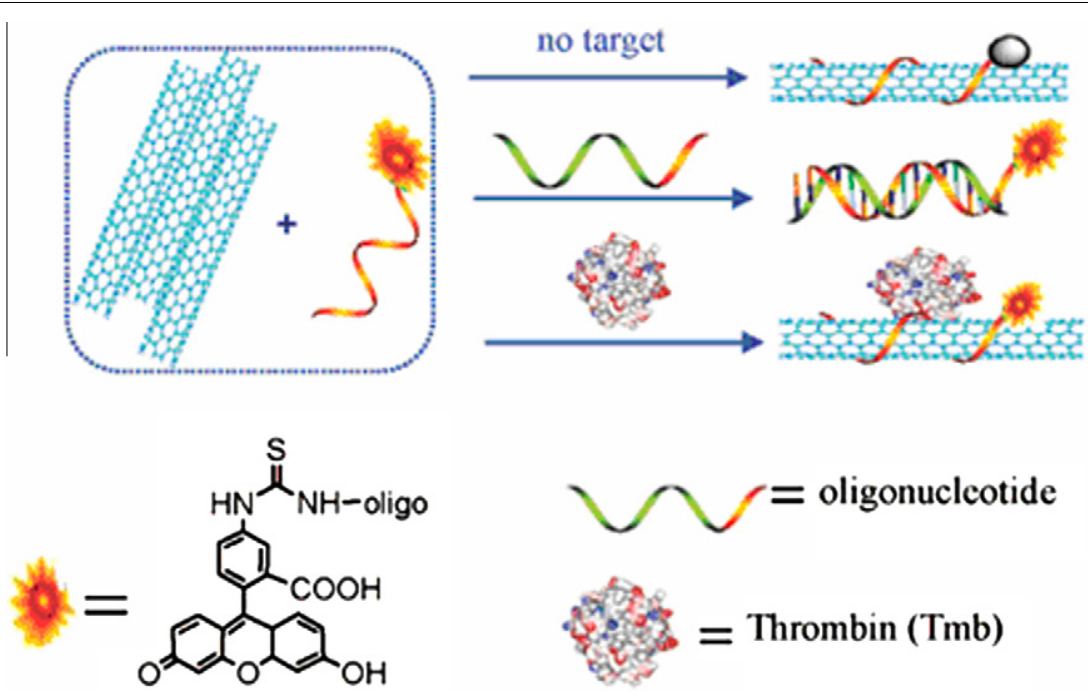

Figure 15. Signaling biomolecular interactions by the assembly of SWCNTs and dye-labeled ssDNA [173]. 


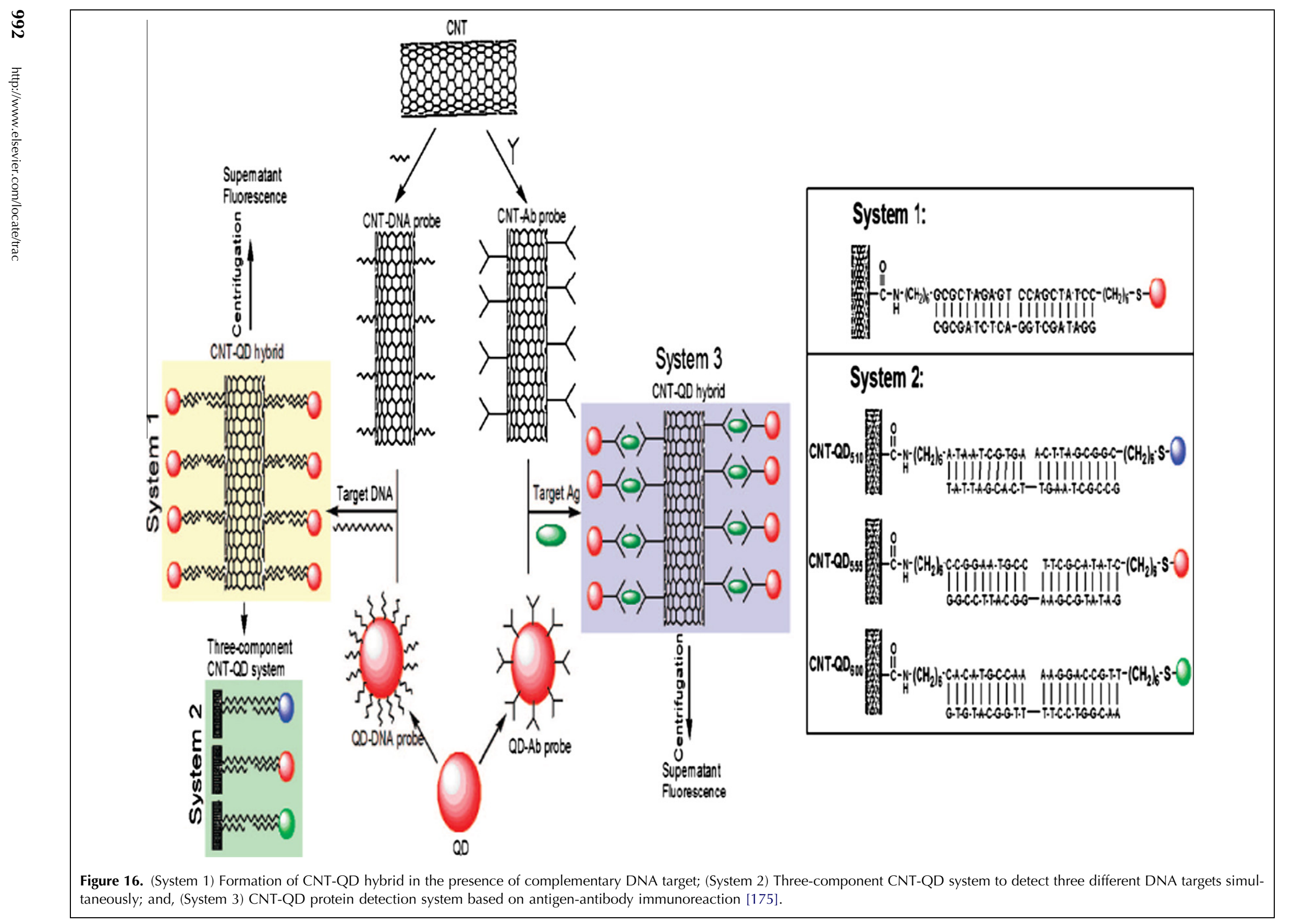


based biosensors. Several sensor designs based on FRET between QDs and dye-labeled biomolecules have been developed [142-144].

Zhou et al. reported preparation and specific label-free DNA detection of a compact, functional QD-DNA conjugate [145]. Target DNA (DNA-T) was immobilized on the surface of the functional QD. Fig. 12 shows the approach. Hybridization of a fluorophore (Alexa 594)-labeled DNA complementary to DNA-T brought the fluorophore in close proximity to the QD, so, when the QD was excited, it efficiently underwent energy transfer to the fluorophore via FRET, producing a dye-fluorescence signal that could be used to detect the labeled complementary DNA probe (route A). Non-complementary probes did not hybridize to the QD-DNA-T conjugate, so they did not participate in the FRET process and were therefore non-fluorescent. This made the removal of such probes unnecessary, a distinct advantage for the FRET-based system. Alternatively, an unlabeled complementary DNA and $\mathrm{EB}$, a dye known to intercalate double-stranded DNAs specifically, were simultaneously introduced into the system. The formation of duplex DNA via hybridization led to EB intercalation, so excitation of the QD led to energy transfer from the QD to EB, producing EB fluorescence that could be used to detect and to quantify unlabeled DNA (route B). This should be more useful from the point of view of applying the sensor, because it did not require the probes to be labeled. Non-complementary probes would not produce any EB FRET signal because they could not hybridize to the QD-DNA-T conjugate, so no EB would intercalate. This system was capable of specific detection of $\mathrm{nM}$ unlabeled complementary DNA at low DNA probe/QD copy numbers via a "signal-on" FRET response.

FRET in QD/DNA/organic-dye conjugates has been used to study DNA hybridization [143,146], cleavage [147], and replication [148]. Most of the reported approaches require covalent conjugation of DNA to the $\mathrm{QD}$ surface [e.g., by 1-ethyl-3-(3-dimethylaminopropyl)carbodiimide- $\mathrm{N}$-hydroxysuccinimide (EDC/NHS) coupling reaction], which often decrease the colloidal stability and/or the emission intensity of QDs [145]. This limitation can be overcome by the use of a sensing platform relying on the electrostatic interaction of dyelabeled DNA with the oppositely charged QD surface [144]. Peng et al. demonstrated a simple DNA-sensing platform on the basis of the FRET between blue-luminescent thioglycolic acid (TGA)-capped CdTe QDs and dye-labeled ssDNA (Fig. 13) [149]. A cationic polymer, poly-(diallyldimethylammonium chloride) (PDADMAC) acted as an "electrostatic linker" to achieve efficient energy transfer from the QD donor to the dye acceptor. The differential interaction of single-stranded and double-stranded DNA with $\mathrm{CdTe}^{+}$resulted in differential changes of FRET efficiency, which was used to recognize the hybridization event. Unlike the FRET-based sensors mentioned above, in this design, covalent immobilization of the probe molecules was not required. This platform provided a homogeneous DNA assay that had all the advantages of a solution-based fluorescence- detection method, but DNA- sequence specificity was achieved with minimal probe modification.

Jiang et al. proposed simultaneous use of CCPs poly[9,9-bis (3-((N,N-dimethyl)- $N$-ethylammonium)pro-

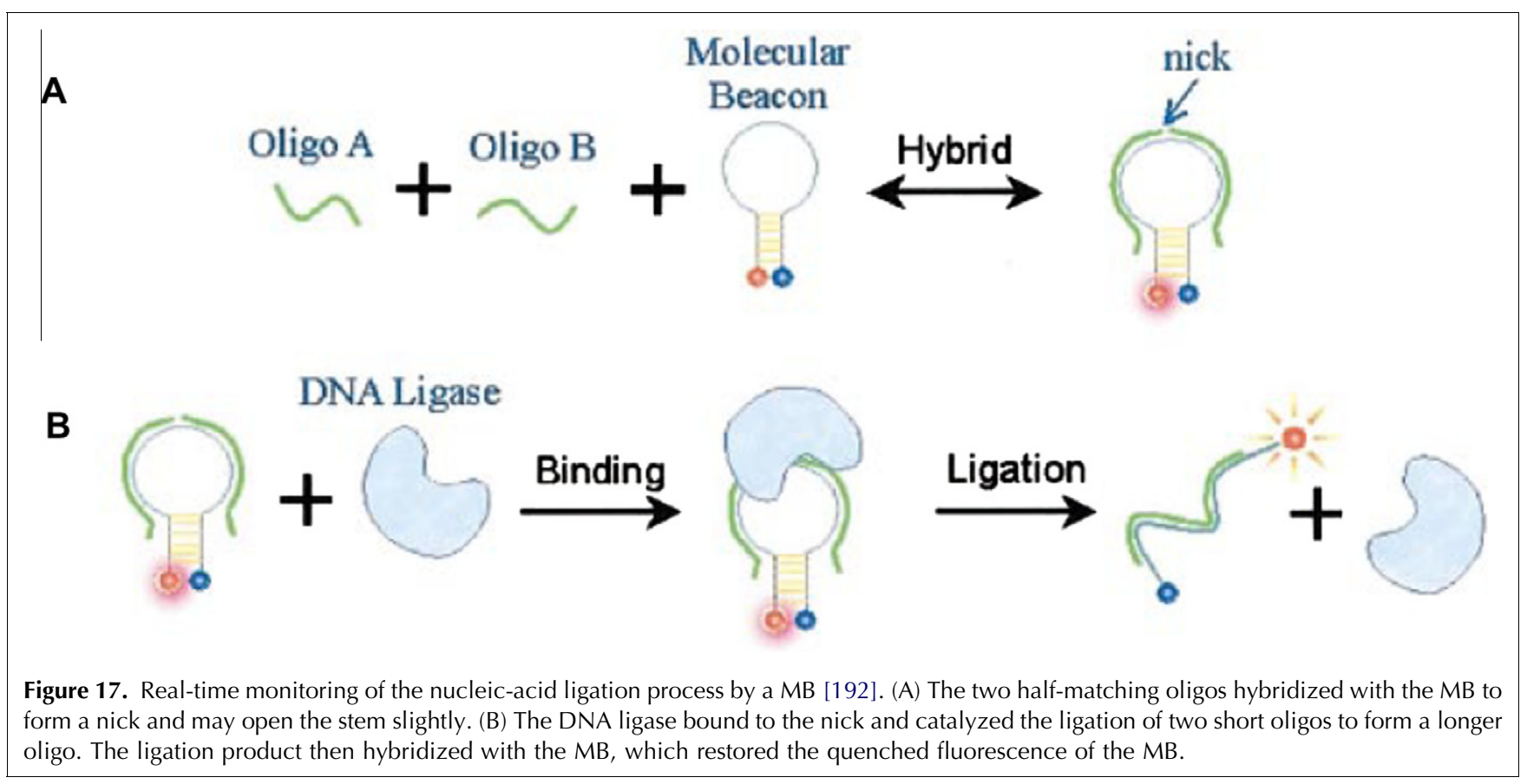



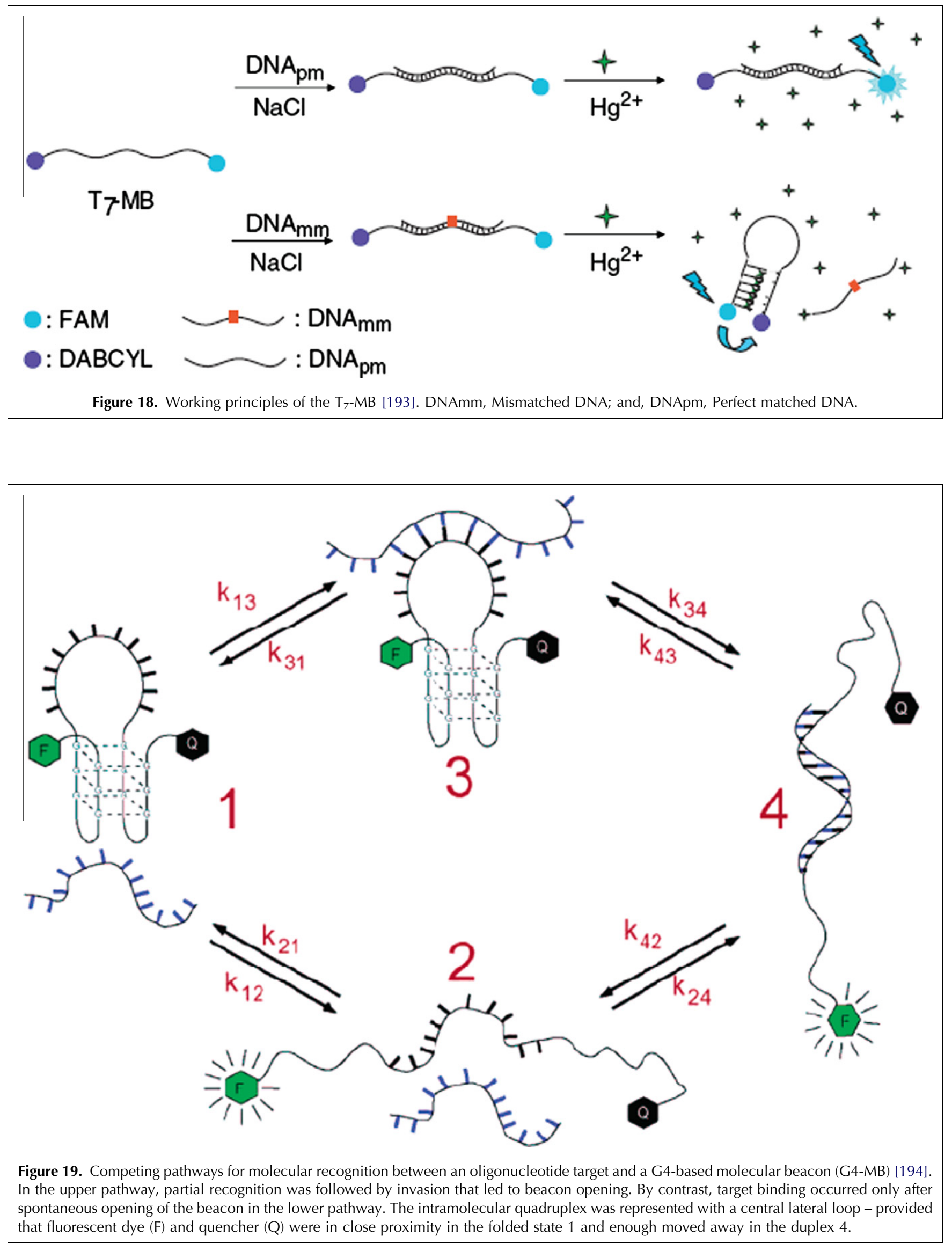
pyl)-2,7-fluorene-alt-1,4-phenylene] dibromide (PDFD) and thioglycolic acid (TGA)-capped CdTe QDs for DNAhybridization detection, which could combine advantages of both light-harvesting and DNA-binding properties of water-soluble polymers with photostability, lightharvesting and FRET-donor properties of QDs [150]. A blue-emitting conjugated polymer with positivelycharged side-chains electrostatically self-assembled on the negatively-charged surface of red-emitting CdTe QDs. The hybrid complex so formed had a net positive charge and thus attracted negatively-charged dye-labeled DNA molecules (Fig. 14). Infrared dye IRD700 was selected as the acceptor dye because its absorbance had no spectral overlap with the emission of PDFD but sufficient overlap with the emission of QDs. Fluorescent-labeled DNA was used to monitor the interaction of the PDFD/QD complex and DNA through a double-FRET process (Fig. 14) FRET 1 from PDFD to QDs and FRET 2 from QDs to the dye on the DNA.

This easy approach provides a reliable signal-on sensing platform for the detection of hybridization events and offers ample potential for future sensitivity improvements of the detection platform proposed. It can also be useful for the development of an alternative strategy with improved selectivity of DNA detection, with cascaded FRET processes taking place to intercalated dyes, thus amplifying optical response from EBbased DNA protocols.

QDs have also become ideal fluorophores for ultrasensitive, multi-color and multiplexing applications in DNA molecular biotechnology and bioengineering [151154] due to their unique properties \{e.g., high chemical stability, resistance to photodegradation, and readilytunable optical properties [155-157]\}.

\subsection{Carbon nanotubes}

Due to their remarkable, unique mechanical, electrical, optical and thermal properties, CNTs, especially singlewalled CNTs (SWCNTs), have been considered the leading candidate for nanodevice applications $[158,159]$. These nanodevices can detect proteins, antibody-antigen interactions, DNA hybridization, and enzymatic reactions [160-165]. The interactions between SWCNTs and DNA have received much attention because SWCNTs have shown promising applications ranging from gene therapy and drug delivery to membrane separation [166-172].

Yang et al. proposed a new sensing platform using a dye-labeled ssDNA and CNTs [173]. The design was based on the attachment of the ssDNA on SWCNTs, with the DNA strand interacting non-covalently with

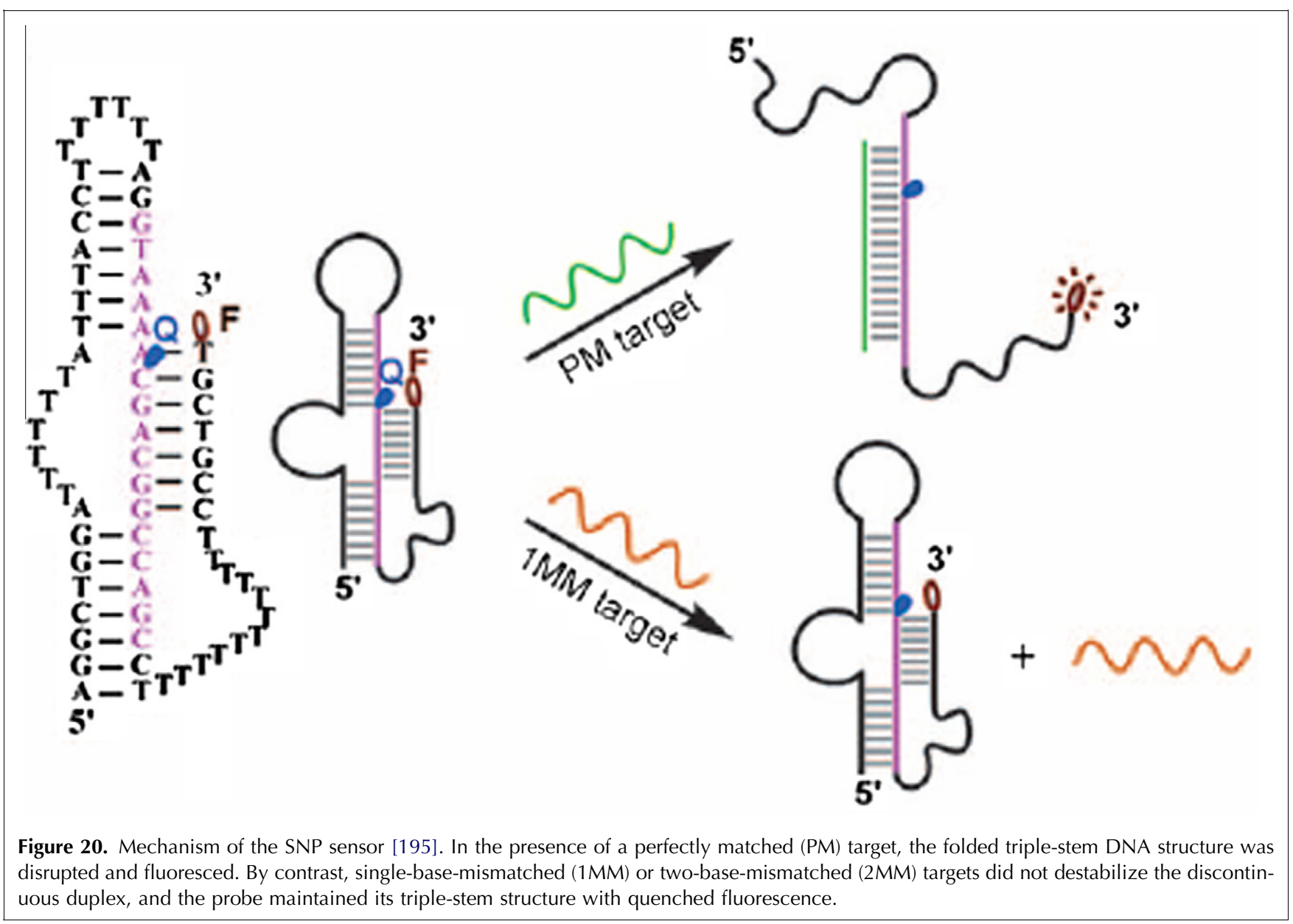




\section{Traditional molecular beacon strategy}

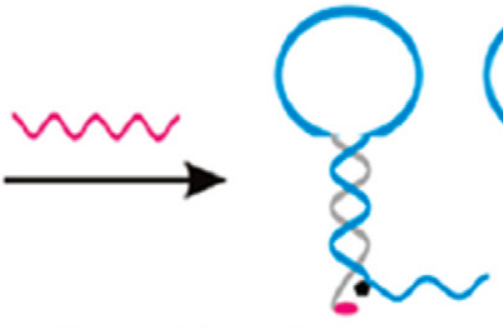

Single target input

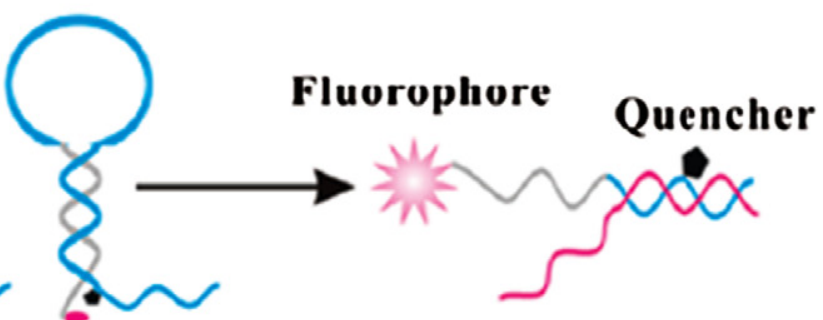

Single signal output

\section{Exonuclease III aided target recycling strategy}

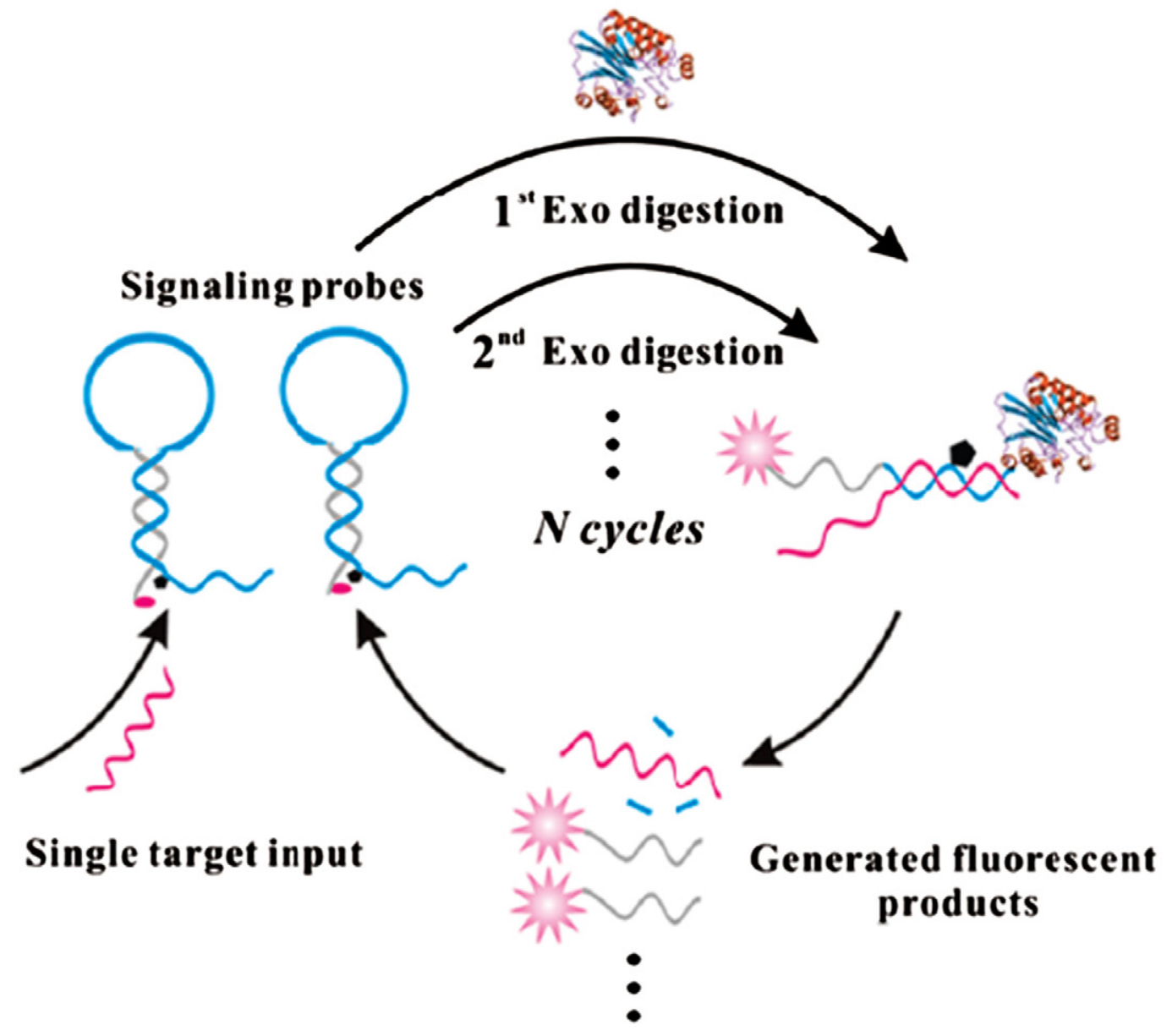

Amplified signal output

Figure 21. (Top) traditional MB DNA assay; and, (bottom) exonuclease III-amplified DNA assay. [196].

SWCNTs by $\pi$ stacking between nucleotide bases and SWCNT sidewalls. The proximity of the SWCNT to the dye effectively quenched the fluorescence in the absence of a target. Conversely, the competitive binding of a target DNA or protein with SWCNTs for the oligonu- cleotide resulted in restoration of fluorescence signal in increments relative to the fluorescence without a target (Fig. 15). This approach can be applied to other types of molecular probes by simply changing the sequences of the ssDNA to a specific target. 


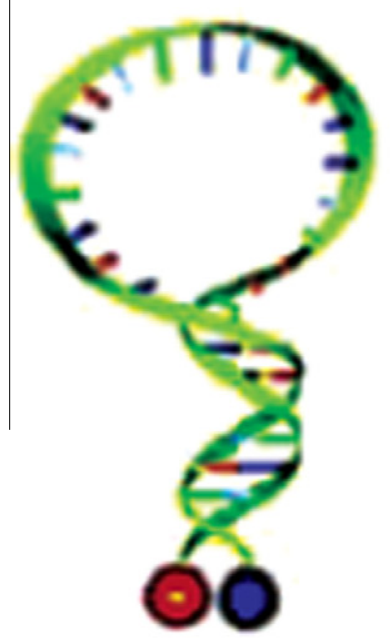

(a)

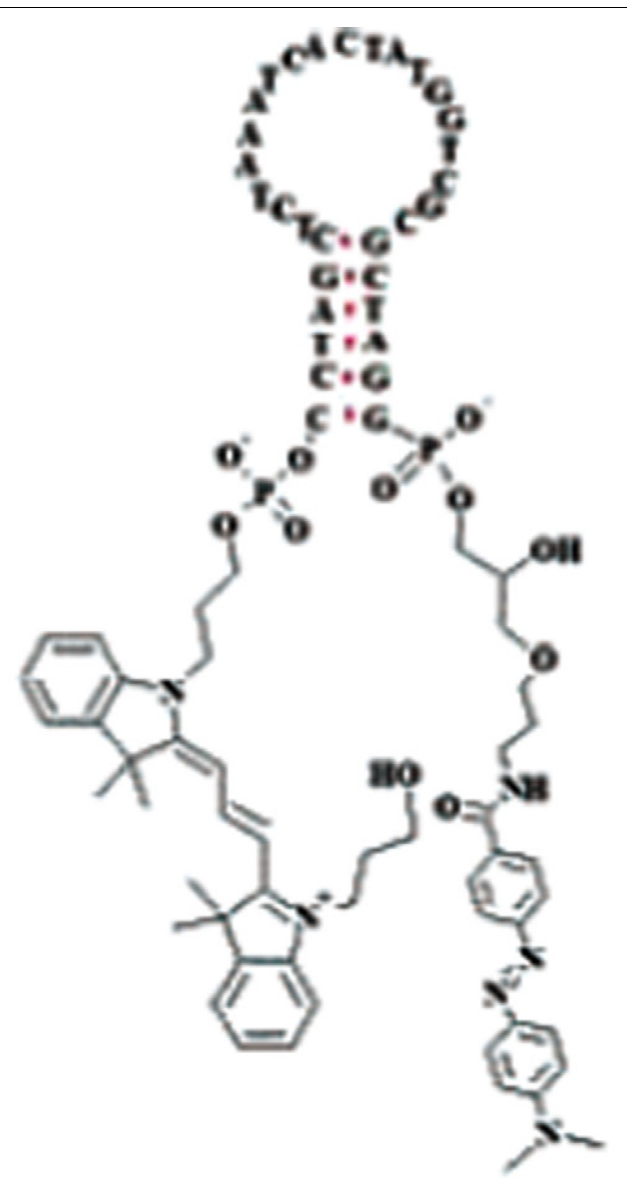

(b)

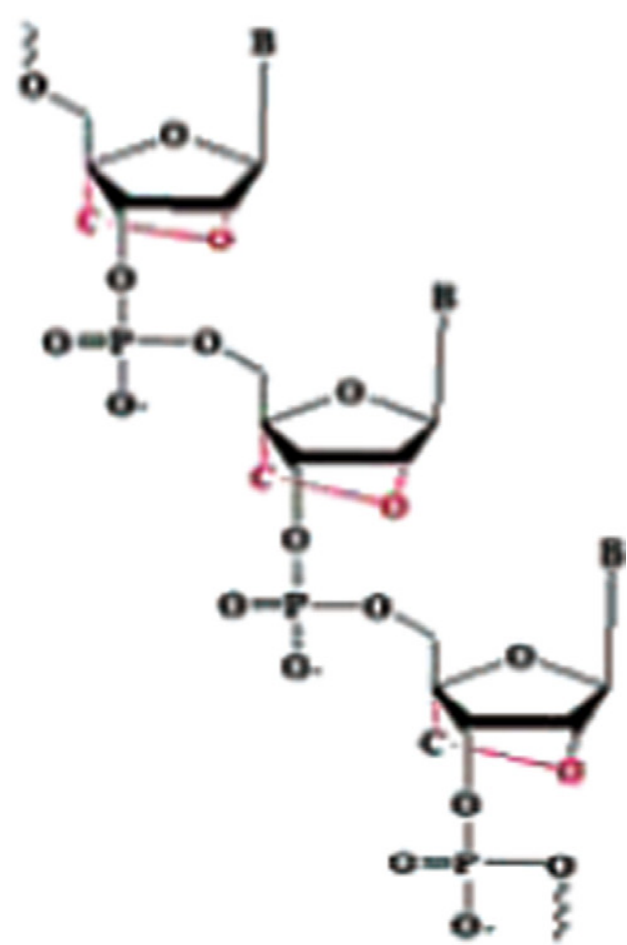

(c)

Figure 22. (a) Cartoon; (b) conformational structure of MB; and, (c) LNA structure [197].

Moreover, the integration of SWCNTs with other unique nanoscale luminescent materials (e.g., QDs) has enabled the manufacture of many novel nanocomposite materials with enhanced structural, mechanical, optical and chemical properties [174] \{e.g., Cui et al. reported a highly selective, ultrasensitive fluorescence detection method for DNA and antigen based on self-assembly of multi-walled CNTs (MWCNTs) and CdSe QDs via oligonucleotide hybridization (Fig. 16) [175]\}. Mercaptoalkyl-oligonucleotide molecules bound to the QDs, while aminoalkyl-oligonucleotides bound to CNTs with -COCl surface groups. QDs and CNTs further assembled into nanohybrids through DNA hybridization in the presence of target-complementary oligonucleotides. The method was achieved with good repeatability with an LOD of $0.2 \mathrm{pM}$ DNA molecules and $0.01 \mathrm{nM}$ antigen molecules. This novel detection system can also be used for multi-component detection and antigen-antibody immunoreaction. The novel system has great potential in applications (e.g., ultrasensitive pathogen DNA or antigen or antibody detection, molecular imaging, and photoelectrical biosensors).
Also, CNTs can be functionalized to achieve improved properties and functions, \{e.g., good biocompatibility and biomolecular recognition capabilities $[176]\}$ e.g., SWCNTs have been developed towards long-term labels in live-cell and optical sensors [177]\}. The majority of investigations have been concerned with drug or gene delivery where an SWCNT, suspended by a biomolecule, is tagged with a fluorophore for observation [178-180]. Further, NA-encapsulated SWCNTs, as photobleachingresistant, non-quenching markers, will thus open up the possibility of new experiments concerning cell proliferation and stem-cell differentiation, long-term labeling of cell populations, and continuous monitoring of the NT environment within vesicles.

In short, NP-based assays have been extensively used for NA detection with sequence specific selectivity. NPbased DNA assays possess the advantage of solid-state sensors, which allow the separation of specific binding from non-specific interactions to achieve sequence-specific detection. The large surface areas of the NPs and their spherical shape also facilitate DNA-probe immobilization with a high density. In addition, NP suspension 
can provide a near-homogeneous environment that facilitates DNA immobilization and hybridization.

\section{Molecular beacons}

An MB is a stem-loop DNA oligonucleotide, which carries a fluorophore and a quencher at the 5'- and 3'-ends. In the absence of the target, these molecules form closed stem-loop structures, in which fluorophore and quencher are in close proximity - and this results in fluorescence quenching. In the presence of DNA or RNA target, the MB forms a complex with it, which forces apart the fluorophore and the quencher. Once fluorophore and quencher are spatially separated, the fluorescence develops under illumination and quantitatively reports on the presence of the target [181-184]. Since the signal-transduction mechanism is built within the MB molecules, no DNA-intercalation reagent or labeling of the target molecule is needed.

There have been a number of different applications of MBs \{e.g., real-time monitoring of PCRs [185], detection of DNA/RNA hybridization in living cells [186], DNA/ RNA biosensors [187], bacterial detection [188], monitoring of enzymatic cleavage [189], investigation of the progression of HIV-1 disease [190], and the study of DNA-protein interactions [191]\}.

Tang et al. developed a simple, efficient assay for monitoring of NA ligation in real time and in homogeneous solutions using MBs [192]. As shown in Fig. 17, the ligation system comprised a DNA ligase, two oligos to be ligated and an $\mathrm{MB}$, in which the combined sequences of the two oligos were complementary to the loop sequence of the MB. In the beginning, each oligo was hybridized to one half of the loop of the MB to form a DNA complex with a nick. This would not open the MB stem completely, but, instead, it would slightly destabilize the stem. When ligase was added, the ligation reaction closed the nick to form a longer DNA strand that was complementary to the $\mathrm{MB}$, resulting in the $\mathrm{MB}$ opening completely. This led to full restoration of fluorescence. According to this mechanism, the MB was not only a probe for the detection of the ligation process, but also a template for the two oligos in the ligation process. Using this method, an efficient bioassay for monitoring the activity of T4 DNA ligase was developed. This was then used to investigate the ligation process under different conditions.

While MBs have been used successfully in DNA assays, their utility for quantification is limited mainly because residual fluorescence arises from the hairpin state, which greatly limits the detection sensitivity of MBs. In addition, when used in detection and visualization of gene expression in living cells, MBs suffer from problems (e.g., endogenous nuclease degradation and non-specific binding by DNA/RNA binding proteins), which result in a false positive signal and significantly limit the general use of MBs in complex biological milieu. To overcome these difficulties, several research groups are engaged in modification of MBs. As a result, some novel MBs have been developed as effective genetic probes.

Lin et al. developed a new sensing strategy for SNPs using a $\mathrm{T}_{7}-\mathrm{MB}$ probe in the presence of $\mathrm{Hg}^{2+}$ [193]. The $\mathrm{T}_{7}$-MB contained a 19-mer loop and a stem of a pair of seven thymidine (T) bases, a carboxyfluorescein (FAM) unit at the 5'- end, and a 4-([4-(dimethylamino) phenyl]azo)benzoic acid (DABCYL) unit at the 3'- end. Upon formation of $\mathrm{Hg}^{2+}-\mathrm{T}_{7}-\mathrm{MB}$ complexes through $\mathrm{T}$ $\mathrm{Hg}^{2+}-\mathrm{T}$ bonding, the conformation of $\mathrm{T}_{7}-\mathrm{MB}$ changed from a random coil to a folded structure, leading to a decreased distance between FAM and DABCYL units and, hence, increased efficiency of FRET between FAM and $\mathrm{DABCYL}$ units, resulting in decreased fluorescence intensity of the MB. In the presence of complementary DNA, double-stranded DNA complexes formed (instead of the $\mathrm{Hg}^{2+}{ }_{-} \mathrm{T}_{7}-\mathrm{MB}$ complexes), with FRET between FAM and DABCYL units occurring to a lesser extent than in the folded structure (Fig. 18). Under the optimal conditions (i.e. $20 \mathrm{nM} \mathrm{T}$ - $\mathrm{MB}, 20 \mathrm{mM} \mathrm{NaCl}, 1.0 \mu \mathrm{M} \mathrm{Hg}^{2+}$, $5.0 \mathrm{mM}$ phosphate buffer solution, $\mathrm{pH}$ 7.4), the linear plot of the fluorescence intensity against the concentration of perfectly matched DNA was linear over the range $2-30 \mathrm{nM}\left(R^{2}=0.991\right)$, with an LOD of $0.5 \mathrm{nM}$ at a signal-to-noise ratio of 3 . Compared with conventional $\mathrm{MB}$ approaches, the $\mathrm{T}_{7}-\mathrm{MB}$ probe provides greater specificity toward perfect-matched DNA over mismatched DNA and is more stable in the presence of high concentrations of salt. When SNPs need to be studied under physiological conditions, the stability and the specificity of the $\mathrm{T}_{7}$-MB probe can be further improved by carefully controlling $\mathrm{Hg}^{2+}$ concentrations and/or the stem length. The superior characteristics of the $\mathrm{T}_{7}-\mathrm{MB}$ probe show its great potential for use in SNP studies.

Bourdoncle et al. evaluated a G-quadruplex-based approach to building MBs (G4-MBs) [194], and provided a versatile strategy for designing efficient MBs. The G4 platform was compatible with building functional MBs that contained long central loops to ensure selective targeting. In the presence of a complementary sequence, the central loop hybridized and formed a duplex that caused the quadruplex stem to open, yielding an important change in fluorescence emission. The presence of a single-base mismatch hindered this opening process, demonstrating that G4-MB could be efficiently used for oligonucleotide discrimination (Fig. 19). With regards to MB-containing stems based on a WatsonCrick duplex, G4-MBs offer unprecedented, easy and predictable new degrees of freedom to tune the experimental conditions for oligonucleotide probing. As an example, the concentration in monovalent and divalent cations can be modified to shift the large temperature range over which sequence discrimination can be per- 
formed. Eventually, G4-MBs offer an interesting route to building MBs that relies on both thermodynamics and kinetics to perform the discrimination of targeted oligonucleotides.

Xiao et al. presented a strategy that combined advantages of MBs and binary probes in a single triplestem DNA structure for robust single-step SNP detection in a homogeneous, room-temperature system without adding exogenous reagents [195]. The triplestem DNA-based SNP sensor comprised a single 68-base DNA strand that had been modified with a CAL Fluor Red 610 (FR610) fluorophore at the 3' terminus and a Black Hole Quencher (BHQ) at an internal position (Fig. 20). At room temperature, the probe self-hybridized into three separate, seven base-pair (bp) WatsonCrick stems that formed a discontinuous, 21-base double helix (Fig. 20, left). In the absence of a target, this relatively rigid triple-stem structure held the fluorophore in close proximity to the quencher; this arrangement resulted in very limited fluorescence. This probe produced a negligible signal in the presence of single-base-mismatched targets, but hybridization to a perfectly matched target induced a significant conformational change that resulted in a large increase in the fluorescence signal (Fig. 20). Importantly, the triplestem probe architecture enabled its sensitivity and selectivity to be tuned towards specific target sequences over a wide temperature range. Given that both DNA and RNA probes can form triple-stem structures, and that the probe can be linked covalently to the surface of a solid-phase substrate, this approach may provide a scalable strategy for high-throughput SNP discovery and analysis with microarray technologies.

Zuo et al. have designed an enzyme-amplified DNAdetection scheme employing a stem-loop DNA MB as the signaling probe [196]. A limitation of traditional MBs is that each target strand hybridizes with (and thus activates) only a single copy of the probe (Fig. 21, top). This 1:1 hybridization ratio limits the gain of the approach and thus its sensitivity. In order to overcome this, the MB they have employed, which was modified with a CAL Fluor Red 610 (FR610) fluorophore at its $5^{\prime}$ terminus and a $\mathrm{BHQ}$ at an internal position, selfhybridized to form a stem-loop structure that contained exonuclease III-resistant $3^{\prime}$ protruding termini (Fig. 21, bottom). This closed structure held the fluorophore in close proximity to the quencher, which resulted in very weak fluorescence. After challenge with a perfectly matched target, the stem-loop structure was opened and formed a double-stranded structure with a blunt $3^{\prime}$ terminus. Exonuclease III catalyzed the step-wise removal of mononucleotides from this terminus, liberating the fluorophore (which, separated from the quencher, then fluoresced) before ultimately releasing the target. The released target then hybridized with another MB probe, whence the cycle started anew.
Thus, a single copy of the target generated many fluorescent MB fragments (Fig. 21, bottom). The approach achieved $\mathrm{pM}$ detection simply by mixing the modified MB, exonuclease III, and complementary target DNA and incubating for $2 \mathrm{~h}$ at $37^{\circ} \mathrm{C}$. The residual exonuclease activity against the unbound $\mathrm{MB}$, which increased background and reduced signal gain at $37^{\circ} \mathrm{C}$, was almost entirely abolished at $4^{\circ} \mathrm{C}$. This in turn led to significantly enhanced signal gain and significantly improved LODs. Under these conditions, the gain of this assay was so great that it could readily detect target over the range $20 \mathrm{aM}-200 \mathrm{fM}$, corresponding to as few as $\sim 600$ molecules in a $50-\mu \mathrm{L}$ sample. This approach thus greatly improves upon the sensitivity of traditional, unamplified MBs.

Wang et al. have designed a novel MB with nucleaseresistant backbone using locked NA (LNA) bases [197]. They prepared a fully-modified LNA-MB and compared its performance with an analogous $\mathrm{MB}$ prepared from DNA monomers (DNA-MB) (Fig. 22a). Both MBs were synthesized with a 19-mer loop and a 6-mer stem, where Cy3 was the 5'-end reporter and DABCYL was the 3'-end quencher (Fig. 22b). Perfectly matched and single central base mismatched targets were used to compare the SNP-detection capability of both MBs. The LNA-MB also displayed selectivity superior to that of DNA-MB. They reasoned that a scaffold that differed as much as possible in the geometric and steric properties from ribose, but retained the repeating charge, would be the most likely to retain the desirable solubility and Watson-Crick basepairing molecular recognition features of natural DNA, while avoiding binding to intracellular DNA/RNA-binding proteins. LNA offered one possible implementation of this strategy. LNA contained one or more LNA-nucleotide monomers with a bicyclic furanose unit locked in a RNA-mimicking sugar conformation (Fig. 22c). The methylene bridge connecting the 2'-oxygen of the ribose and the 4'-carbon endowed LNA with many attractive properties (e.g., high binding affinity, excellent basemismatch-discrimination capability, and decreased susceptibility to nuclease digestion).

Engineering MBs with an LNA backbone generates a novel LNA-MBs with three distinguishing features critically important for biological applications, whereas the normal DNA-MB suffers from limitations:

- first, high thermo-stability of such an LNA-MB probe, combined with the excellent affinity for a complementary sequence, makes this probe especially useful under stringent experimental conditions;

- second, the selectivity of a MB can be further enhanced with an LNA backbone, which is of great significance in SNP analysis; and,

- third, LNA-MBs resist not only nuclease digestion but also binding of single-stranded DNA binding protein, which reduces false-positive signals for MB applications in complex biological environments. 
As MBs have been widely used in many areas of research, studies with LNA-MBs will provide highly valuable information for improving the performance of MBs.

\section{Future outlook}

Some novel approaches to DNA detection have provided excellent selectivity with high sensitivity, comparable to many PCR-based approaches without the need for enzymatic amplification. The superior, novel properties of these new functional materials present many unique opportunities for development of DNAdetecting techniques. Although a great deal of progress has already been made in DNA analysis, much more work is needed to put homogeneous, fluorescence-based DNA-detection platforms into DNA-microarray (or chip) applications. Fluorescence-based microarray techniques that do not require target-DNA labeling will be used for gene mapping, transcription profiling and genome comparison by allowing high-throughput screening of thousands of genes on a single slide. Compared with traditional microarray work, targets must be labeled with a fluorescent marker before hybridization. That adds to the cost, complexity and time required to process the arrays. Working towards a label-free system will help to reduce the cost and the time associated with target-labeling procedures. Other label-free detection methods exist, but typically require sophisticated instruments (e.g., mass spectrometers), which require substantial maintenance and are less suitable for highthroughput detection.

With a strong demand for quantitative studies of genomic information, much more advanced biomolecular recognition DNA probes, which have many attractive properties (e.g., high binding affinity, excellent basemismatch-discrimination capability, and decreased susceptibility to nuclease digestion) will be designed and synthesized. DNA-analysis methods based on these properties will become powerful tools for in vivo and in vitro gene-sequencing and gene-expression studies.

\section{Acknowledgement}

We thank the National Natural Science Foundation of China (No. 20907060) for financial support.

\section{References}

[1] W. Vercoutere, M. Akeson, Curr. Opin. Chem. Biol. 6 (2002) 816.

[2] J. Wang, Nucleic Acids Res. 28 (2000) 3011.

[3] G. Ramsay, Nat. Biotechnol. 16 (1998) 40.

[4] A. Hassibi, H. Vikalo, J.L. Riechmann, B. Hassibi, Nucleic Acids Res. 37 (2009) e132.

[5] C. Debouck, P.N. Goodfellow, Nat. Genet. 21 (1999) 48.
[6] J. Zhang, S. Song, L. Zhang, L. Wang, H. Wu, D. Pan, C. Fan, J. Am. Chem. Soc. 128 (2006) 8575.

[7] Y.P. Bao, M. Huber, T.F. Wei, U.R. Muller, Nucleic Acids Res. 33 (2005) e15.

[8] Z. Wan, Y. Wang, S.S.C. Li, L. Duan, J. Zhai, J. Biochem. Mol. Biol. 38 (2005) 399.

[9] M.M.C. Cheng, G. Cuda, Y.L. Bunimovich, M. Ferrari, Curr. Opin. Chem. Biol. 10 (2006) 11.

[10] J.C. Avarre, P. De Lajudie, G. Bna, J. Microbiol. Methods 69 (2007) 242.

[11] W.J. Qin, L.Y.L. Yung, Nucleic Acids Res. 35 (2007) e111.

[12] B.M. Zeglis, J.K. Barton, J. Am. Chem. Soc. 128 (2006) 5654.

[13] C. Dose, O. Seitz, Bioorg. Med. Chem. 16 (2008) 65.

[14] W. Jin, X. Lin, S. Lv, Y. Zhang, Q. Jin, Y. Mu, Biosens. Bioelectron. 24 (2009) 1266.

[15] M. Piliarik, L. Párová, J. Homola, Biosens. Bioelectron. 24 (2009) 1399.

[16] M. Minunni, S. Tombelli, J. Fonti, M. Buiatti, J. Am. Chem. Soc. 127 (2005) 7966.

[17] T.G. Drummond, M.G. Hill, J.K. Barton, Nat. Biotechnol. 21 (2003) 1192.

[18] S.J. Park, T.A. Taton, C.A. Mirkin, Science (Washington, DC) 295 (2002) 1503.

[19] C.A. Heid, J. Stevens, K.J. Livak, P.M. Williams, Genome Res. 6 (1996) 986.

[20] E. Socher, L. Bethge, A. Knoll, N. Jungnick, A. Herrmann, O. Seitz, Angew. Chem., Int. Ed. Engl. 47 (2008) 9555.

[21] D. Baumstark, H.A. Wagenknecht, Angew. Chem., Int. Ed. Engl. 47 (2008) 2612.

[22] T.N. Grossmann, L. Roglin, O. Seitz, Angew. Chem., Int. Ed. Engl. 46 (2007) 5223.

[23] C.J. Yang, K. Martinez, H. Lin, W. Tan, J. Am. Chem. Soc. 128 (2006) 9986.

[24] I. Willner, R. Barton, B. Willner, Biosens. Bioelectron. 22 (2007) 1841 .

[25] K.D. Barbee, W. Huang, Anal. Chem. 80 (2008) 2149.

[26] M. Mir, M. Alvarez, O. Azzaroni, L. Tiefenauer, W. Knoll, Anal. Chem. 80 (2008) 6554.

[27] U. Feldkamp, C.M. Niemeyer, Angew. Chem., Int. Ed. Engl. 45 (2006) 1856.

[28] N.L. Rosi, C.A. Mirkin, Chem. Rev. 105 (2005) 1547.

[29] T.A. Taton, C.A. Mirkin, R.L. Letsinger, Science (Washington, DC) 289 (2000) 1757.

[30] L. Wang, C. Lofton, M. Popp, W. Tan, Bioconjugate Chem. 18 (2007) 610.

[31] H. Liu, H. Wang, Z. Shi, H. Wang, W. Tan, Z. Lu, Nucleic Acids Res. 34 (2006) e4.

[32] L.Q. Chu, R. Forch, W. Knoll, Angew. Chem., Int. Ed. Engl. 46 (2007) 4944.

[33] E.S. Baker, J.W. Hong, B.S. Gaylord, G.C. Bazan, M.T. Bowers, J. Am. Chem. Soc. 128 (2006) 8484.

[34] W.R. Algar, M. Massey, U.J. Krull, Trends Anal. Chem. 28 (2009) 292.

[35] A.A. Goulko, F. Li, X.C. Le, Trends Anal. Chem. 28 (2009) 878.

[36] E.J. Fechter, B. Olenyuk, P.B. Dervan, J. Am. Chem. Soc. 127 (2005) 16685.

[37] L. An, L. Liu, S. Wang, G.C. Bazan, Angew. Chem., Int. Ed. Engl. 48 (2009) 4372.

[38] R. Moller, W. Fritzsche, Curr. Pharm. Biotechnol. 8 (2007) 274.

[39] H.M.E. Azzazy, M.M.H. Mansour, S.C. Kazmierczak, Clin. Chem. 52 (2006) 1238.

[40] Z. Wang, Y. Lu, J. Mater. Chem. 19 (2009) 1788.

[41] B.A.J. Giesendorf, J.A.M. Vet, S. Tyagi, H.J. Blom, Clin. Chem. 44 (1998) 482.

[42] A. Moliton, R.C. Hiorns, Polym. Int. 53 (2004) 1397.

[43] K.E. Achyuthan, T.S. Bergstedt, L. Chen, D.G. Whitten, J. Mater. Chem. 15 (2005) 2648. 
[44] B. Liu, G.C. Bazan, J. Am. Chem. Soc. 126 (2004) 1942.

[45] H.A. Ho, K. Dore, M. Boissinot, M.G. Bergeron, R.M. Tanguay, D. Boudreau, M. Leclerc, J. Am. Chem. Soc. 127 (2005) 12673.

[46] P.S. Heeger, A.J. Heeger, Proc. Natl. Acad. Sci. USA 96 (1999) 12219.

[47] S.W. Thomas, G.D. Joly, T.M. Swager, Chem. Rev. 107 (2007) 1339.

[48] M. Kang, O.K. Nag, R.R. Nayak, S. Hwang, H. Suh, H.Y. Woo, Macromolecules 42 (2009) 2708.

[49] B. Liu, G.C. Bazan, Chem. Mater. 16 (2004) 4467.

[50] F. Feng, F. He, L. An, S. Wang, Y. Li, D. Zhu, Adv. Mater. 20 (2008) 2959.

[51] H.A. Ho, M. Leclerc, J. Am. Chem. Soc. 126 (2004) 1384.

[52] F. He, Y.L. Tang, S. Wang, Y.L. Li, D.B. Zhu, J. Am. Chem. Soc. 127 (2005) 12343.

[53] Q.L. Fan, Y. Zhou, X.M. Lu, X.Y. Hou, W. Huang, Macromolecules 38 (2005) 2927.

[54] I.B. Kim, U.H.F. Bunz, J. Am. Chem. Soc. 128 (2006) 2818.

[55] X. Feng, X. Duan, L. Liu, L. An, F. Feng, S. Wang, Langmuir 24 (2008) 12138.

[56] Y. Jin, R. Yang, H. Suh, H.Y. Woo, Macromol. Rapid Commun. 29 (2008) 1398.

[57] Y. Zhang, Z. Li, Y. Cheng, Chem. Commun. (2008) 6579.

[58] Y.Q. Huang, X.F. Liu, Q.L. Fan, C.F.W. Huang, Biosens. Bioelectron. 24 (2009) 2973.

[59] H. Peng, C. Soeller, J. Travas-Sejdic, Chem. Commun. (2006) 3735.

[60] K. Lee, L.K. Povlich, J. Kim, Adv. Funct. Mater. 17 (2007) 2580.

[61] B. Li, C. Qin, T. Li, L. Wang, S. Dong, Anal. Chem. 81 (2009) 3544.

[62] K.E. Achyuthan, T.S. Bergstedt, L. Chen, W. Xia, D.G. Whitten, J. Mater. Chem. 15 (2005) 2648.

[63] P.K. Lo, H.F. Sleiman, Macromolecules 41 (2008) 5590.

[64] B. Liu, G.C. Bazan, Macromol. Rapid Commun. 28 (2007) 1804.

[65] K.Y. Pu, Z. Fang, B. Liu, Adv. Funct. Mater. 18 (2008) 1321.

[66] H.A.A. Attar, A.P. Monkman, Adv. Funct. Mater. 18 (2008) 2498.

[67] B. Liu, G.C. Bazan, Proc. Natl. Acad. Sci. USA 102 (2005) 589.

[68] C. Sun, B.S. Gaylord, J.W. Hong, B. Liu, G.C. Bazan, Nat. Protoc. 2 (2007) 2148 .

[69] K. Lee, J.M. Rouillard, T. Pham, E. Gulari, J. Kim, Angew. Chem., Int. Ed. Engl. 46 (2007) 4667.

[70] A. Cattani-Scholz, D. Pedone, M. Dubey, S. Neppl, B. Nickel, P. Feulner, J. Schwartz, G. Abstreiter, M. Tornow, ACS Nano 2 (2008) 1653.

[71] C.B. Murray, C.R. Kagan, M.G. Bawendi, Annu. Rev. Mater. Sci. $30(2000) 545$

[72] A.P. Alivisatos, Science (Washington, DC) 271 (1996) 933.

[73] X.G. Peng, L. Manna, W.D. Yang, J. Wickham, E. Scher, A. Kadavanich, A.P. Alivisatos, Nature (London) 404 (2000) 59.

[74] P.M. Ajayan, Chem. Rev. 99 (1999) 1787.

[75] H. Dai, Acc. Chem. Res. 35 (2002) 1035.

[76] M.M. Alvarez, J.T. Khoury, T.G. Schaaff, M.N. Shafigullin, I. Vezmar, R.L. Whetten, J. Phys. Chem. B 101 (1997) 3706.

[77] M. Bruchez, M. Moronne, P. Gin, S. Weiss, A.P. Alivisatos, Science (Washington, DC) 281 (1998) 2013.

[78] S. Chen, R.S. Ingram, M.J. Hostetler, J.J. Pietron, R.W. Murray, R.L. Whetten, Science (Washington, DC) 280 (1998) 2098.

[79] D.L. Pelecky, R.D. Rieke, Chem. Mater. 8 (1996) 1770.

[80] F.J. Himpsel, J.E. Ortega, G.J. Mankey, R.F. Willis, Adv. Phys. 47 (1998) 511.

[81] L.N. Lewis, Chem. Rev. 93 (1993) 2693.

[82] T. Pellegrino, S. Kudera, T. Liedl, A.M. Javier, L. Manna, W.J. Parak, Small 1 (2005) 48.

[83] I. Willner, R. Baron, B. Willner, Biosens. Bioelectron. 22 (2007) 1841.

[84] E. Katz, I. Willner, Angew. Chem., Int. Ed. Engl. 43 (2004) 6042.
[85] J.M. Nam, C.S. Thaxton, C.A. Mirkin, Science (Washington, DC) 301 (2003) 1884

[86] M. Trau, B.J. Battersby, Adv. Mater. 13 (2001) 975.

[87] A.P.R. Johnston, B.J. Battersby, G.A. Lawrie, M. Trau, Chem. Commun. (2005) 848.

[88] S.O. Meade, M.Y. Chen, M.J. Sailor, G.M. Miskelly, Anal. Chem. 81 (2009) 2618

[89] W. Tan, K. Wang, X. He, T. Drake, L. Wang, R.P. Bagwe, Med. Res. Rev. 24 (2004) 621

[90] D. Knopp, D. Tang, R. Niessner, Anal. Chim. Acta 647 (2009) 14.

[91] J.E. Smith, L. Wang, W. Tan, Trends Anal. Chem. 25 (2006) 848.

[92] Y. Wang, B. Liu, Anal. Chem. 79 (2007) 7214.

[93] S.B. Lee, D.T. Mitchell, L. Trofin, T.K. Nevanen, H. Soderlund, C.R. Martin, Science (Washington, DC) 296 (2002) 2198.

[94] C.C. Chen, Y.C. Liu, C.H. Wu, C.C. Yeh, M.T. Su, Y.C. Wu, Adv. Mater. 17 (2005) 404.

[95] Y. Wang, B. Liu, Chem. Commun. (2007) 3553.

[96] R.P. Bagwe, L.R. Hilliard, W. Tan, Langmuir 22 (2006) 4357.

[97] J.A. Sioss, R.L. Stoermer, M.Y. Sha, C.D. Keating, Langmuir 23 (2007) 11334.

[98] S.R. Corrie, G.A. Lawrie, M. Trau, Langmuir 22 (2006) 2731.

[99] S. Zheng, H. Zhang, E. Ross, T.V. Le, M.J. Wirth, Anal. Chem. 79 (2007) 3867.

[100] X. Zhao, R. Tapec-Dytioco, W. Tan, J. Am. Chem. Soc. 125 (2003) 11474

[101] X. Zhou, J. Zhou, Anal. Chem. 76 (2004) 5302.

[102] C.Z. Li, K.B. Male, S. Hrapovic, J.H.T. Luong, Chem. Commun. (2005) 3924.

[103] C.S. Thaxton, D.G. Georganopoulou, C.A. Mirkin, Clin. Chim. Acta 363 (2006) 120.

[104] M. Mehrabi, R. Wilson, Small 3 (2007) 1491.

[105] L. Dyadyusha, H. Yin, S. Jaiswal, T. Brown, J.J. Baumberg, F.P. Booy, T. Melvin, Chem. Commun. (2005) 3201.

[106] S.J. Hurst, M.S. Han, A.K.R. Lytton-Jean, C.A. Mirkin, Anal. Chem. 79 (2007) 7201.

[107] J.Y. Kim, J.S. Lee, Nano Lett 9 (2009) 4564.

[108] L. Wang, J. Li, S. Song, D. Li, C. Fan, J. Phys. D: Appl. Phys. 42 (2009) 203001.

[109] B. Dubertret, M. Calame, A.J. Libchaber, Nat. Biotechnol. 19 (2001) 365.

[110] C.K. Kim, R.R. Kalluru, J.P. Singh, A. Fortner, J. Griffin, G.K. Darbha, P.C. Ray, Nanotechnology 17 (2006) 3085.

[111] P.C. Ray, A. Fortner, G.K. Darbha, J. Phys. Chem. 110 (2006) 20745.

[112] J.H. Kim, R.A. Estabrook, G. Braun, B.R. Lee, N.O. Reich, Chem. Commun. (2007) 4342.

[113] S. Song, Z. Liang, J. Zhang, L. Wang, G. Li, C. Fan, Angew. Chem., Int. Ed. Engl. 48 (2009) 8670.

[114] J.M. Nam, S.I. Stoeva, C.A. Mirkin, J. Am. Chem. Soc. 126 (2004) 5932

[115] G. Festag, A. Steinbruck, A. Wolff, A. Csaki, R. Moller, W. Fritzsche, J. Fluores. 15 (2005) 161.

[116] G.A. Blab, L. Cognet, S. Berciaud, I. Alexandre, D. Husar, J. Remacle, B. Lounis, Biophys. J: Biophys. Lett. (2006) L13.

[117] S. Tokonami, H. Shiigi, T. Nagaoka, Anal. Chem. 80 (2008) 8071.

[118] F. Qiu, D. Jiang, Y. Ding, J. Zhu, L.L. Huang, Angew. Chem., Int. Ed. Engl. 47 (2008) 5009.

[119] P. Alivisatos, Nat. Biotechnol. 22 (2004) 47.

[120] X. Michalet, F.F. Pinaud, L.A. Bentolila, J.M. Tsay, S. Weiss, Science (Washington, DC) 307 (2005) 538 .

[121] M.Y. Han, X. Gao, J.Z. Su, S. Nie, Nat. Biotechnol. 19 (2001) 631.

[122] W.C.W. Chan, S. Nie, Science (Washington, DC) 281 (1998) 2016. 
[123] J.M. Klostranec, W.C.W. Chan, Adv. Mater. 18 (2006) 1953.

[124] E.R. Goldman, A.R. Clapp, G.P. Anderson, H.T. Uyeda, J.M. Mauro, I.L. Medintz, H. Mattoussi, Anal. Chem. 76 (2004) 684.

[125] S. Wang, N. Mamedova, N.A. Kotov, W. Chen, J. Studer, Nano Lett. 2 (2002) 817.

[126] D. Gerion, F. Pinaud, S.C. Williams, W.J. Parak, D. Zanchet, S. Weiss, A.P. Alivisatos, J. Phys. Chem. B 105 (2001) 8861.

[127] W.J. Parak, D. Gerion, D. Zanchet, A.S. Woerz, T. Pellegrino, A.P. Alivisatos, Chem. Mater. 14 (2002) 2113.

[128] X. Gao, Y. Cui, R.M. Levenson, L.W.K. Chung, S. Nie, Nat. Biotechnol. 22 (2004) 969.

[129] T. Pellegrino, L. Manna, S. Kudera, T. Liedl, D. Koktysh, W.J. Parak, Nano Lett. 4 (2004) 703.

[130] X. Wu, H. Liu, J. Liu, K.N. Haley, J.A. Treadway, J.P. Larson, N. Ge, F. Peale, M.P. Bruchez, Nat. Biotechnol. 21 (2003) 41.

[131] T. Nann, Chem. Commun. (2005) 1735.

[132] B. Dubertret, P. Skourides, D.J. Norris, V. Noireaux, A.H. Brivanlou, A. Libchaber, Science (Washington, DC) 298 (2002) 1759.

[133] C.Y. Zhang, H.C. Yeh, M.T. Kuroki, T.H. Wang, Nat. Mater. 4 (2005) 826.

[134] G.P. Mitchell, C.A. Mirkin, R.L. Letsinger, J. Am. Chem. Soc. 121 (1999) 8122

[135] D. Zhou, J.D. Piper, C. Abell, D. Klenerman, D.J. Kang, L. Ying, Chem. Commun. (2005) 4807.

[136] G. Gill, I. Willner, I. Shweky, U. Banin, J. Phys. Chem. B 109 (2005) 23715.

[137] M. Levy, S.F. Cater, A.D. Ellington, ChemBioChem 6 (2005) 2163.

[138] S. Dwarakanath, J.G. Bruno, A. Shastry, T. Phillips, A. John, A. Kumar, L.D. Stephenson, Biochem. Biophys. Res. Commun. 325 (2004) 739.

[139] E.R. Goldman, I.L. Medintz, J.L. Whitley, A. Hayhurst, A.R. Clapp, H. Mattoussi, J. Am. Chem. Soc. 127 (2005) 6744.

[140] I.L. Medintz, A.R. Clapp, H. Mattoussi, E.R. Goldman, G. Fisher, J.M. Mauro, Nat. Mater. 2 (2003) 630

[141] E. Chang, J.S. Miller, J. Sun, W.W. Yu, V.L. Colvin, R. Drezek, J.L. West, Biochem. Biophys. Res. Commun. 334 (2005) 1317.

[142] A.R. Clapp, I.L. Medintz, H. Mattoussi, ChemPhysChem 7 (2006) 47.

[143] W.R. Algar, U.J. Krull, Langmuir 25 (2009) 633.

[144] J. Lee, Y. Choi, J. Kim, E. Park, R. Song, ChemPhysChem 10 (2009) 806.

[145] D. Zhou, L. Ying, X. Hong, E.A. Hall, C. Abell, D. Klenerman, Langmuir 24 (2008) 1659.

[146] C.S. Wu, J.M. Cupps, X. Fan, Nanotechnology 20 (2009) 305502-1.

[147] R. Gill, I. Willner, I. Shweky, U. Banin, J. Phys. Chem. B 109 (2005) 23715.

[148] F. Patolsky, R. Gill, Y. Weizmann, T. Mokari, U. Banin, I. Willner, J. Am. Chem. Soc. 125 (2003) 13918.

[149] H. Peng, L. Zhang, T.H.M. Kjallman, C. Soeller, J. Travas-Sejdic, J. Am. Chem. Soc. 129 (2007) 3048.

[150] G. Jiang, A.S. Susha, A.A. Lutich, F.D. Stefani, J. Feldmann, A.L. Rogach, ACS Nano 3 (2009) 4127.

[151] W.C.W. Chan, D.J. Maxwell, X. Gao, R.E. Bailey, M. Han, S. Nie, Curr. Opin. Biotechnol. 13 (2002) 40.

[152] Y. Choi, H.P. Kim, S.M. Hong, J.Y. Ryu, S.J. Han, R. Song, Small 5 (2009) 2085.

[153] R.Q. Liang, W. Li, Y. Li, C. Tan, J.X. Li, Y.X. Jin, K.C. Ruan, Nucleic Acids Res 33 (2005) e17.

[154] W.R. Algar, U.J. Krull, Anal. Chem. 82 (2010) 400.

[155] T. Kim, M. Noh, H. Lee, S.W. Joo, S.Y. Lee, K. Lee, J. Phys. Chem. B 113 (2009) 14487.

[156] H.C. Yeh, Y.P. Ho, I.M. Shih, T.H. Wang, Nucleic Acids Res. 34 (2006) e35.
[157] J.R. Lakowicz, I. Gryczynski, Z. Gryczynski, C.J. Murphy, J. Phys. Chem. B 103 (1999) 7613.

[158] Y. Lin, S. Taylor, H. Li, L. Qu, W. Wang, J. Mater. Chem. 14 (2004) 527.

[159] P.M. Ajayan, O.Z. Zhou, Top. Appl. Phys. 80 (2001) 391.

[160] K. Bradley, M. Briman, A. Star, Nano Lett. 4 (2004) 253.

[161] R.J. Chen, H.C. Choi, S. Bangsaruntip, E. Yenilmez, X. Tang, Q. Wang, J. Am. Chem. Soc. 126 (2004) 1563.

[162] S. Boussaad, N.J. Tao, R. Zhang, T. Hopson, L.A. Nagahara, Chem. Commun. (2003) 1502.

[163] A. Star, E. Tu, J. Niemann, C.S. Joiner, C. Valcke, Proc. Natl. Acad. Sci. USA 103 (2006) 921.

[164] X. Tang, S. Bangsaruntip, N. Nakayama, E. Yenilmez, Y.I. Chang, Q. Wang, Nano Lett. 6 (2006) 1632.

[165] A. Star, V. Joshi, T.R. Han, V.P. Altoe, J.F. Stoddart, Org. Lett. 6 (2004) 2089.

[166] N.W.S. Kam, M. O'Connell, J.A. Wisdom, H. Dai, Proc. Natl. Acad. Sci. USA 102 (2005) 11600.

[167] K.A. Williams, P.T.M. Veenhuizen, B.G. de la Torre, R. Eritja, C. Dekker, Nature (London) 420 (2002) 761.

[168] C. Hu, Y. Zhang, G. Bao, Y. Zhang, M. Liu, Z. Wang, J. Phys. Chem. B 109 (2005) 20072.

[169] M. Zheng, A. Jagota, E.D. Semke, B.A. Diner, R.S. Mcleen, S.R. Lustig, Nat. Mater. 2 (2003) 338.

[170] M. Zheng, A. Jagota, M.S. Strano, A.P. Santos, P. Barone, S.G. Chou, Science (Washington, DC) 302 (2003) 1545.

[171] H. Gao, Y. Kong, Annu. Rev. Mater. Res. 34 (2004) 123.

[172] R. Singh, D. Pantarotto, D. McCarthy, O. Chaloin, J. Hoebeke, C. Partidos, J. Am. Chem. Soc. 127 (2005) 4388.

[173] R. Yang, Z. Tang, J. Yan, H. Kang, Y. Kim, Z. Zhu, W. Tan, Anal. Chem. 80 (2008) 7408.

[174] Z. Zhou, H.G. Kang, M.L. Clarke, S.H. De Paoli Lacerda, M. Zhao, J.A. Fagan, A. Shapiro, T. Nguyen, J. Hwang, Small 5 (2009) 2149.

[175] D. Cui, B. Pan, H. Zhang, F. Gao, R. Wu, J. Wang, R. He, T. Asahi, Anal. Chem. 80 (2008) 7996.

[176] L. Meng, C. Fu, O. Lu, Prog. Nat. Sci. 19 (2009) 801.

[177] D.A. Heller, S. Baik, T.E. Eurell, M.S. Strano, Adv. Mater. 17 (2005) 2793.

[178] N.W.S. Kam, H.J. Dai, J. Am. Chem. Soc. 127 (2005) 6021

[179] D. Pantarotto, R. Singh, D. McCarthy, M. Erhardt, J.P. Briand, M. Prato, K. Kostarelos, A. Bianco, Angew. Chem., Int. Ed. Engl. 43 (2004) 5242.

[180] Q. Lu, J.M. Moore, G. Huang, A.S. Mount, A.M. Rao, L.L. Larcom, P.C. Ke, Nano Lett. 4 (2004) 2473.

[181] W. Tan, K. Wang, T.J. Drake, Curr. Opin. Chem. Biol. 8 (2004) 547.

[182] W. Tan, X. Fang, J. Li, X. Liu, Chem. Eur. J. 6 (2000) 1107.

[183] Y. Li, X. Zhou, D. Ye, Biochem. Biophys. Res. Commun. 373 (2008) 457.

[184] M. Rajendran, A.D. Ellington, Nucleic Acids Res. 31 (2003) 5700.

[185] A.S. Piatek, S. Tyagi, A.C. Pol, A. Telenti, L.P. Miller, F.R Kramer, D. Alland, Nat. Biotechnol. 16 (1998) 359.

[186] P. Conlon, C.J. Yang, Y. Wu, Y. Chen, K. Martinez, N.J. Turro, W. Tan, J. Am. Chem. Soc. 130 (2008) 336.

[187] H. Kuhn, V.V. Demidov, J.M. Coull, M.J. Fiandaca, B.D. Gildea, M.D. Frank-Kamenetskii, J. Am. Chem. Soc. 124 (2002) 1097

[188] W. Chen, G. Martinez, A. Mulchandani, Anal. Biochem. 280 (2000) 166.

[189] J.J. Li, R. Geyer, W. Tan, Nucleic Acids Res. 28 (2000) e52.

[190] L.G. Kostrikis, S. Tyagi, M.M. Mhlanga, D.D. Ho, F.R. Kramer, Science (Washington, DC) 279 (1998) 1228.

[191] J.J. Li, X. Fang, S.M. Schuster, W. Tan, Angew. Chem., Int. Ed. Engl. 39 (2000) 1049. 
[192] Z. Tang, K. Wang, W. Tan, J. Li, L. Liu, Q. Guo, X. Meng, C. Ma, S. Huang, Nucleic Acids Res. 31 (2003) e148.

[193] Y.M. Lin, H.T. Ho, C.C. Huang, H.T. Chang, Nucleic Acids Res. 36 (2008) e123.

[194] A. Bourdoncle, A.E. Torres, C. Gosse, L. Lacroix, L. Jullien, J.L. Mergny, J. Am. Chem. Soc. 128 (2006) 11094.
[195] Y. Xiao, K.J.I. Plakos, X. Lou, R.J. White, J. Qian, K.W. Plaxco, H.T. Soh, Angew. Chem., Int. Ed. Engl. 48 (2009) 4354.

[196] X. Zuo, F. Xia, Y. Xiao, K.W. Plaxco, J. Am. Chem. Soc. 132 (2010) 1816.

[197] L. Wang, C.J. Yang, C.D. Medley, S.A. Benner, W. Tan, J. Am. Chem. Soc. 127 (2005) 15664. 